\title{
Bio-inspired geotechnical engineering: principles, current work, opportunities and challenges
}

\author{
ALEJANDRO MARTINEZ*, JASON DEJONG†, IDIL AKIN $\ddagger$, ALI ALEALI§, CHLOE ARSON\|, \\ JARED ATKINSONף, PAOLA BANDINI§, TUGCE BASER**, RODRIGO BORELA\|, \\ ROSS BOULANGER $\uparrow$, MATTHEW BURRALL $\uparrow$, YUYAN CHEN $\uparrow$, CLINT COLLINS $\dagger \dagger$, \\ DOUGLAS CORTES $\S$, SHENG DAI\|, THEODORE DEJONG $\dagger$, EMANUELA DEL DOTTORE $\S$, \\ KELLY DORGAN\|\|, RICHARD FRAGASZY $\|$, J. DAVID FROST\|, ROBERT FULL***,

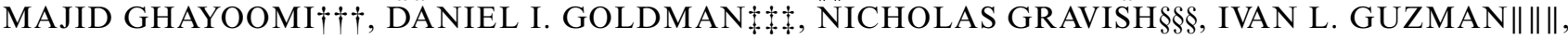

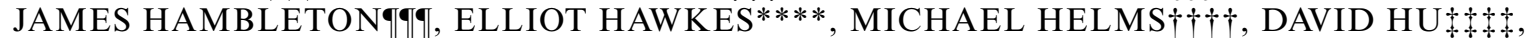 \\ LIN HUANG $\uparrow$, SICHUAN HUANG $\S \S \S$, CHRISTOPHER HUNT \|\|\|\| , DUNCAN IRSCHICK $\mid \uparrow \oplus \uparrow$, \\ HAI THOMAS LIN*****, BRET LINGWALL $+\dagger+\dagger$, ALEN MARR $++\dagger++$, BARBARA MAZZOLAI $\S$, \\ BENJAMIN MCINROE $\S \S \S \S$, TEJAS MURTHY \|\|\|\|$\|$, KYLE O’HARA $\uparrow$, MARIANNE PORTER $\| \uparrow \uparrow \uparrow \uparrow$,

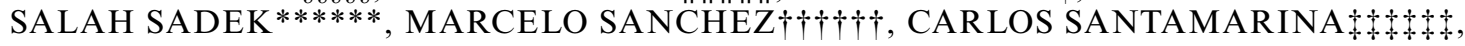

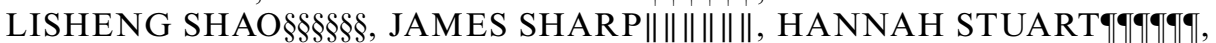 \\ HANS HENNING STUTZ*******, ADAM SUMMERS $\uparrow+\dagger+\dagger \dagger \dagger$, JULIAN TAO $\S \S \S$, MICHAEL TOLLEY $\S \S$, \\ LAURA TREERS ++++++ , KURTIS TURNBULL $\S \S \S \S \S \S$, ROGELIO VALDES \|\|\|\|\|\|\|\| , \\ LEON VAN PAASSEN $\S \S \S \S$, GIOACCHINO VIGGIANI $\uparrow \uparrow \uparrow \uparrow \uparrow \uparrow \uparrow$, DANIEL WILSON********,

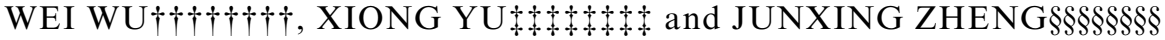

\begin{abstract}
A broad diversity of biological organisms and systems interact with soil in ways that facilitate their growth and survival. These interactions are made possible by strategies that enable organisms to accomplish functions that can be analogous to those required in geotechnical engineering systems. Examples include anchorage in soft and weak ground, penetration into hard and stiff subsurface materials and movement in loose sand. Since the biological strategies have been 'vetted' by the process of natural selection, and the functions they accomplish are governed by the same physical laws in both the natural and engineered environments, they represent a unique source of principles and design ideas for addressing geotechnical challenges. Prior to implementation as engineering solutions, however, the differences in spatial and temporal scales and material properties between the biological environment and engineered system must be addressed. Current bio-inspired geotechnics research is addressing topics such as soil excavation and penetration, soil-structure interface shearing, load transfer between foundation and anchorage elements and soils, and mass and thermal transport, having gained inspiration from organisms such as worms, clams, ants, termites, fish, snakes and plant roots. This work highlights the potential benefits to both geotechnical engineering through new or improved solutions and biology through understanding of mechanisms as a result of cross-disciplinary interactions and collaborations.
\end{abstract}

KEYWORDS: anchors \& anchorages; in situ testing; penetrometers; piles \& piling

Manuscript received 28 May 2020; revised manuscript accepted 9 February 2021. Published online ahead of print 27 May 2021.

Discussion on this paper closes on 1 December 2022, for further details see p. ii.

Published with permission by the ICE under the CC-BY 4.0 license. (http://creativecommons.org/licenses/by/4.0/)

* Department of Civil and Environmental Engineering, University of California Davis, Davis, CA, USA (corresponding author: amart@ ucdavis.edu) (Orcid:0000-0003-4649-925X).

$\dagger$ Department of Civil and Environmental Engineering, University of California Davis, Davis, CA, USA.

t Department of Civil and Environmental Engineering, Washington State University, Pullman, WA, USA.

$\S$ Department of Civil Engineering, New Mexico State University, Las Cruces, NM, USA.

|| School of Civil and Environmental Engineering, Georgia Institute of Technology, Atlanta, GA, USA

II Integrated Geotechnology, Norwegian Geotechnical Institute, Oslo, Norway.

** Department of Civil and Environmental Engineering, University of Illinois Urbana Champaign, Urbana Champaign, IL, USA

†† Department of Biological Sciences, California State University Sacramento, Sacramento, CA, USA.

\#. Department of Plant Sciences, University of California Davis, Davis, CA, USA.

$\$ \S$ Istituto Italiano di Tecnologia, Pontedera, Italy.

||| Department of Marine Sciences, Dauphin Island Sea Laboratory, Dauphin Island, AL, USA.

qศ Formerly National Science Foundation, Washington, DC, USA.

*** Department of Integrative Biology, University of California Berkeley, Berkeley, CA, USA

$\dagger+$ Department of Civil and Environmental Engineering, University of New Hampshire, Durham, NH, USA.

tt School of Physics, Georgia Institute of Technology, Atlanta, GA, USA.

$\S \S \S$ Department of Mechanical Engineering, University of California San Diego, La Jolla, CA, USA.

||||| Department of Construction Management and Civil Engineering Technology, New York City College of Technology, Brooklyn, NY,

USA (Orcid:0000-0002-8983-8402).

१ฯ Department of Civil and Environmental Engineering, Northwestern University, Evanston, IL, USA.

**** Department of Mechanical Engineering, University California Santa Barbara, Santa Barbara, CA, USA. 


\section{INTRODUCTION}

Advances in engineering that allow humans to harvest renewable wind and thermal energy, facilitate exploration of remote areas and increase the sustainability of construction materials and processes, along with emerging issues such as growing population densities in urban centres and climate change, continually challenge geotechnical engineers to develop more efficient, sustainable and multifunctional solutions. Recent research has advanced solutions that seek to address these challenges. For example, thermoactive foundations provide structural support and thermal regulation of the internal temperature of buildings (e.g. Brandl, 2006; Amatya et al., 2012; Murphy et al., 2015) and bio-cementation techniques such as microbially induced calcite precipitation provide ground improvement alternatives that reduce the use of materials with a high carbon dioxide footprint, such as cement (e.g. DeJong et al., 2006; Whiffin et al., 2007). However, there are numerous other challenges that have not been resolved. Site characterisation under existing structures such as dams and buildings or even on extra-terrestrial bodies is often unfeasible; soilstructure interfaces often represent weak links in the mechanical stability of engineered systems, such as landfill liners and capping systems; and new foundation solutions for offshore wind turbines in deep water that are economical yet stable under complex loading conditions are needed.

The biological strategies that living organisms have evolved to accomplish certain functions represent a rich source of principles and design ideas for translation to human-made systems (Dudley \& Gans, 1991; Vogel, 1998; Autumn et al., 2002; Irschick \& Higham, 2016). A broad diversity of organisms, including many plants, mammals, reptiles, birds, fish, insects, molluscs, microbes and fungi, interact with soil in various ways that facilitate their growth, survival and reproduction. These interactions include penetration of hard and stiff materials, anchorage in soft soils, movement in loose granular materials and control of mass and thermal transport in granular materials. Since these tasks are governed by the same physical laws in both the natural and engineered environments, bio-inspiration can stimulate the generation of innovative alternative solutions to address geotechnical challenges.

In the last decade, bio-inspiration has led to advances in topics such as soil penetration and excavation, soil-structure interfaces, load transfer and anchorage and mass and heat transport. For example, research on the excavation behaviour of ants has shown that they use only a fraction of a per cent of the energy that human technologies require to excavate the same amount of soil (from $10^{4}$ to $10^{5} \mathrm{~J} / \mathrm{m}^{3}$ for ants as opposed to $10^{7}$ to $10^{8} \mathrm{~J} / \mathrm{m}^{3}$ for tunnel-boring machines (Soga, 2011)). Similarly, tree root systems can be tens to hundreds of times more efficient in transferring load per unit volume or mass material used than conventional shallow and deep foundations (Burrall et al., 2020). These and other similar examples illustrate the advancements that bio-inspired design can bring to geotechnical engineering. The goals of this paper are to provide a synthesis of the potential benefits, challenges and needs for the bio-inspired geotechnics field, to summarise design methods and relevant concepts from the broader bio-inspired design field and to provide a review of ongoing research in bio-inspired geotechnics.

\section{THE ROLE OF BIO-INSPIRATION IN ADDRESSING GEOTECHNICAL CHALLENGES}

Bio-inspired design consists of abstracting and adapting a biological solution to solve an engineering problem. This is possible in part because the biological world contains a diversity in designs, materials and mechanical systems of varying complexity to solve particular problems (Vogel, 2013). However, the differences between the spatial and temporal scales relevant to biological processes and geotechnical engineering applications can be significant and must be addressed (DeJong et al., 2017; Frost et al., 2017). Specifically, living organisms (i.e. animals and plants) are typically much smaller and live at shallower depths (i.e. at lower overburden stresses) than many geotechnical systems. Thus, bio-inspiration requires careful evaluation of the upscaling potential before biological strategies can be implemented to develop geotechnical solutions. Fig. 1(a)

††† Center for Education Integration, Science, Mathematics, and Computing, Georgia Institute of Technology, Atlanta, GA, USA.

HA Department of Mechanical Engineering, Georgia Institute of Technology, Atlanta, GA, USA.

$\S \S \S \S$ School of Sustainable Engineering and the Built Environment, Arizona State University, Tempe, AZ, USA.

\|\|\|\|$\|$ Geosyntec Consultants, Oakland, CA, USA.

ศศๆ Department of Biology, University Massachusetts Amherst, Amherst, MA, USA.

$* * * * *$ Department of Civil and Environmental Engineering, Louisiana State University, Baton Rouge, LA, USA.

$+1+\dagger$ Department of Civil and Environmental Engineering, South Dakota School of Mines and Technology, Rapid City, SD, USA.

tttt Geocomp, Acton, MA, USA.

$\S \S \S \S$ Biophysics Graduate Group, University of California Berkeley, Berkeley, CA, USA.

||||||||| Indian Institute of Science, Bengaluru, India.

१ศศ $\uparrow \uparrow$ Department of Biological Sciences, Florida Atlantic University, Boca Raton, FL, USA.

$* * * * *$ Department of Civil and Environmental Engineering, American University of Beirut, Beirut, Lebanon.

$\lceil\dagger \dagger \dagger \dagger$ Department of Civil and Environmental Engineering, Texas A\&M University, College Station, TX, USA.

Htt Department of Energy Resources and Petroleum Engineering, King Abdullah University of Science and Technology, Thuwal, Saudi Arabia.

$\S \S \S \S \S \S$ Malcolm Drilling, San Francisco, CA, USA.

|| || || ||||| Conetec Inc., Vancouver, Canada.

ศศศศศศ Department of Mechanical Engineering, University of California Berkeley, Berkeley, CA, USA.

$* * * * * * *$ Department of Civil and Architectural Engineering, Aarhus University, Aarhus, Denmark.

††

H+1 Department of Mechanical Engineering, University of California Berkeley, Berkeley, CA, USA.

$\S \$ \$ \$ s \$ \S$ Department of Biology, Western University, London, Canada.

\|\|\|\|\|\|\|\| Department of Mechanical Engineering, Universidad Nacional Autonoma de Mexico, Mexico City, Mexico.

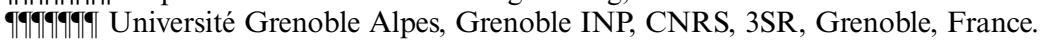

$* * * * * * * *$ Center for Geotechnical Modeling, University of California Davis, Davis, CA, USA.

$+\dagger^{\prime}+\dagger_{\dagger}+\dagger$ Institute of Geotechnical Engineering, University of Natural Resources and Life Sciences, Vienna, Austria.

$+1+1+$ Department of Civil Engineering, Case Western University, Cleveland, OH, USA.

$\S \S \S \S \S \S \S \S$ Department of Civil, Construction, and Environmental Engineering, Iowa State University, Ames, IA, USA. 
illustrates a process for bio-inspired design, along with examples of research in three areas of ongoing research. This process for bio-inspired design consists of: $(a)$ understanding the biological principles; $(b)$ identifying a biological strategy; $(c)$ formulating an hypothesis regarding the underlying processes of the biological strategy; $(d)$ testing the hypothesis; $(e)$ evaluating the upscaling potential of the biological strategy; and $(f)$ evaluating the systems-level performance.

The first example outlined in Fig. 1(b) is for a bio-inspired solution for geotechnical engineering interfaces that mobilise directionally dependent interfacial friction. These surfaces are inspired by the belly scales of snakes and could benefit applications such as foundations for wind turbines. An initial hypothesis is developed based on the understanding of load transfer mechanisms at soil-structure interfaces along with quantification of the morphology of the scales of different snake species, which revealed their asymmetric sawtooth shape (Martinez et al., 2019). Frictional directionality is hypothesised to be due to passive resistances generated as the soil is sheared against the sharp edge of the bio-inspired scales (i.e. cranial direction), which are absent when the soil is sheared along the scales (i.e. caudal direction). The performance of these surfaces has been tested through laboratory experiments and their implementation towards deep foundations has been evaluated through centrifuge modelling (O'Hara \& Martinez, 2020; Martinez \& O'Hara, 2021). In the future, piles with snakeskin-inspired surfaces could be deployed to decrease the soil resistance during installation and increase the skin friction during tensile pullout loading. Figs 1(c) and 1(d) present how the same approach has been applied towards the development of self-burrowing probes for site characterisation and sensor deployment in locations with limited access through numerical modelling, cavity expansion analyses and field prototypes (Chen et al., 2020, 2021; Tao et al., 2020), as well as towards the development of root-inspired anchorage systems for retaining structures through laboratory and field testing (Mallett et al., 2018; Burrall et al., 2020).

\section{BACKGROUND, CONSIDERATIONS AND} CHALLENGES FOR BIO-INSPIRED GEOTECHNICS

Biological strategies can be viewed as successful solutions for accomplishing tasks that are analogous to those required in engineered systems. However, there are important differences between the natural and engineered environments in terms of spatial and temporal scales and materials. In addition, biological strategies are often complex due to their
Bio-inspiration process

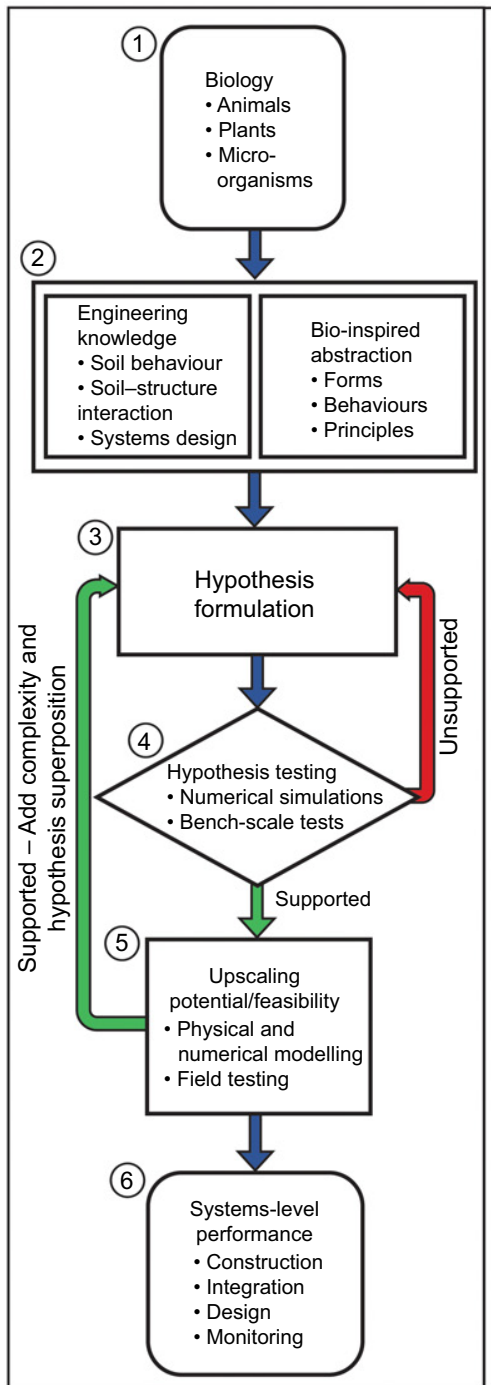

(a)

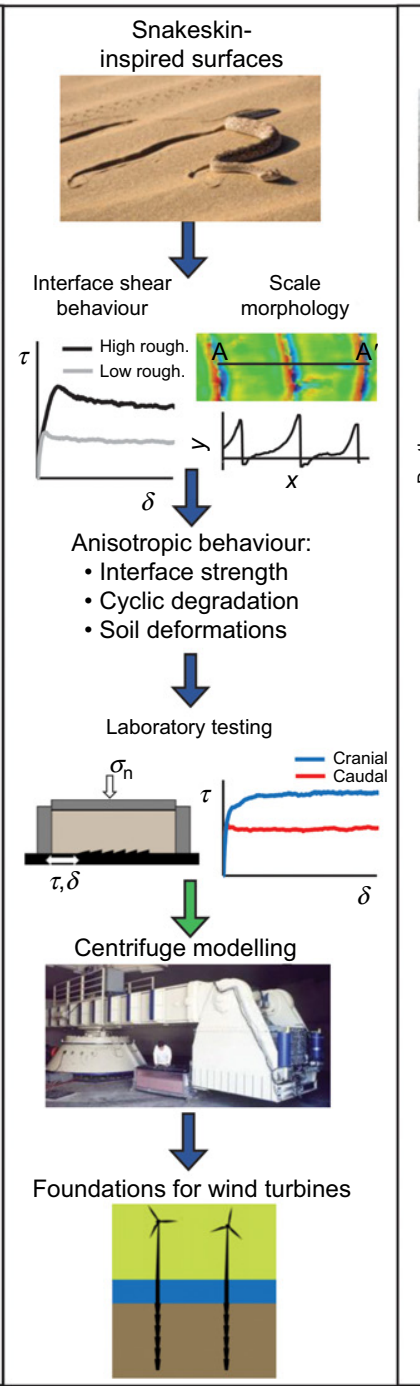

(b)

Applications for geotechnical challenges

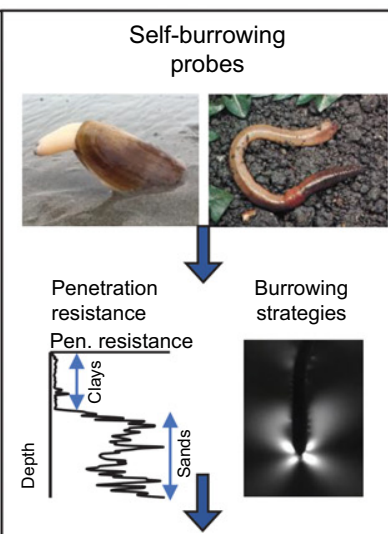

Efficient penetration:

- Penetration resistance

- Peristalsis

- Anchorage
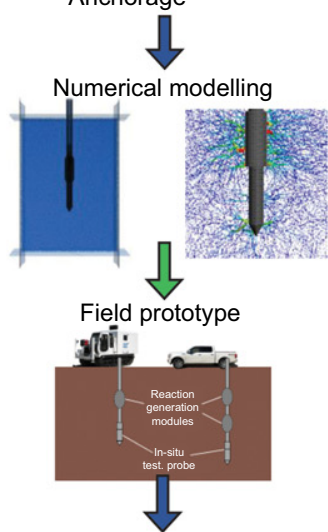

Autonomous sensors network

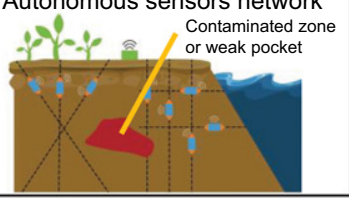

(c)

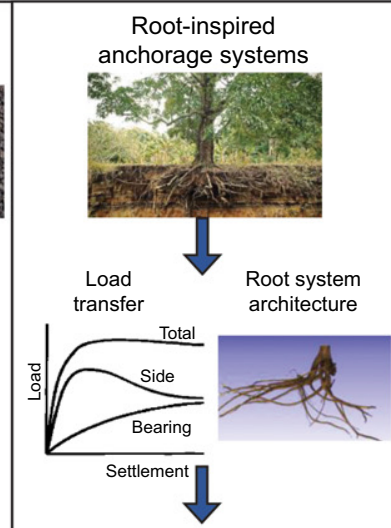

Axial and lateral capacity:

- Load redistribution

- Material stiffness

- Root cooperation

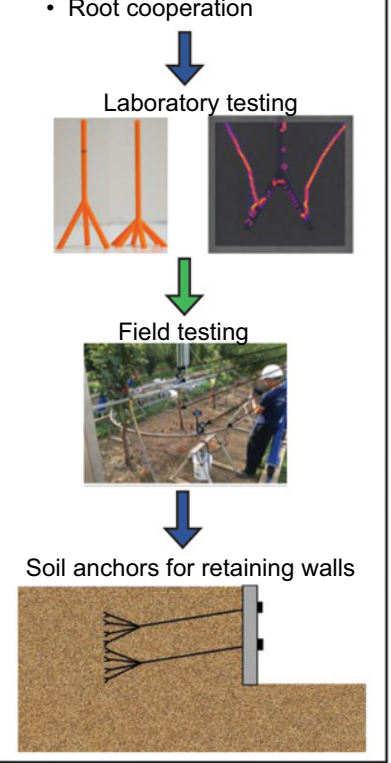

(d)

Fig. 1. Bio-inspired research in geotechnics. (a) Bio-inspiration process and application to (b) snakeskin-inspired surfaces, (c) self-burrowing probes and (d) root-inspired anchorage and foundation systems 
multi-functionality and adaptability, posing challenges for scientists and engineers to define them unambiguously. This section provides a synthesis of concepts, considerations and challenges for research in bio-inspired geotechnics.

\section{Biology, evolution and bio-inspiration}

Evolution is the process through which gene expressions adapt over consecutive generations to increase species performance in the surrounding environment (Turcotte \& Levine, 2016). The individuals that possess behavioural, physiological or morphological traits that give them an advantage to survive will be favoured by natural selection (Endler, 1986). The variations that increase the likelihood to survive and reproduce will prevail, while variations that make individuals less likely to survive will disappear. The disciplines of evolutionary biology, biomechanics and ecology are concerned with understanding biological mechanisms and materials, form-function relationships and interactions between organisms and their environment. These mechanisms, materials, relationships and interactions constitute the basis of the biological strategies that are important for engineering and technology development because they represent the only known alternatives to human technology (Vogel, 1998).

Bio-inspired and bio-mimetic design have been used in fields such as manufacturing, nanoengineering and computing for several decades (e.g. Ueda et al., 2001; Alting et al., 2003; Kar, 2016). Herein, bio-inspiration is defined as a broad term referring to the application of biological strategies to solve engineering problems, while bio-mimetics or bio-mimicry typically refers to direct translation of biological shapes and configurations to engineering problems. It is noted that bio-inspired geotechnics differs from the growing sub-field of bio-mediated geotechnics, which directly uses living organisms or biological processes to improve engineering properties, such as the use of bacteria to produce bio-cementation, the use of bio-films to reduce permeability and the use of vegetation to stabilise slopes and reduce soil erosion by means of mechanical reinforcement (e.g. Danjon et al., 2008; DeJong et al., 2013).

\section{Challenges and considerations for bio-inspired geotechnics}

Biological strategies are limited and constrained based on the ancestry of an organism and the reliance on certain biomaterials. Animals and plants need to simultaneously survive, grow, attract mates and depart from ancestral forms to develop new strategies (Vogel, 1998; Fish \& Beneski, 2014). For this reason, biological strategies are multifunctional, redundant, robust and efficient; however, they are not optimised for a single specific function and they work under a principle of 'just enough' (Lauder, 1982, 1996; Fish \& Beneski, 2014; Irschick \& Higham, 2016). Their translation to the engineering domain must thus be accomplished with careful considerations of the differences in demands and conditions between the biological and engineered systems.

As noted earlier, one of the most important challenges in implementing bio-inspired solutions towards engineering is the differences in relevant spatial and temporal scales between the biological and engineering domains. For instance, geotechnical systems, such as foundations, tunnels and anchors, can reach sizes of metres to tens of metres in diameter and hundreds of metres to kilometres in length, while living organisms are typically smaller than $10 \mathrm{~cm}$ in diameter and shorter than several metres in length (except for some large trees). Another difference is the magnitude of applied stresses and forces. Specifically, most geotechnical structures are installed at depths between 5 and $50 \mathrm{~m}$ below the ground surface and are subjected to stresses in the $\mathrm{kPa}$ to $\mathrm{MPa}$ range, whereas most living organisms inhabit depths from a few cm (e.g. worms, ants) to a few metres (e.g. tree roots) where the stresses range from the $\mathrm{Pa}$ to $\mathrm{kPa}$ range.

It is well established that the forces that control the behaviour of soils depend on the particle size as well as the depth (e.g. Santamarina, 2001; Santamarina et al., 2001). As such, biological strategies that depend on certain types of forces can be limited to specific particle sizes and depths. To illustrate this, Fig. 2(a) shows the effect of particle size on different forces that can be experienced by spherical particles. When the particles are subjected to an effective stress of $1 \mathrm{MPa}$ (equivalent depth of about $100 \mathrm{~m}$ of saturated soil), the skeletal forces govern the interactions for particles with a diameter greater than about $0.3 \mu \mathrm{m}(0.0003 \mathrm{~mm})$; however, at an effective stress of $1 \mathrm{kPa}$ (equivalent depth of about $10 \mathrm{~cm}$ of saturated soil), capillary and drag forces can prevail over skeletal forces for particles with a diameter smaller than about $200 \mu \mathrm{m}(0.2 \mathrm{~mm})$ and $4 \mu \mathrm{m}(0.004 \mathrm{~mm})$, respectively. Biological strategies can also be closely tied to the scale at which they are used by the organisms. Allometry analyses, or the study of how processes change with body size, can be

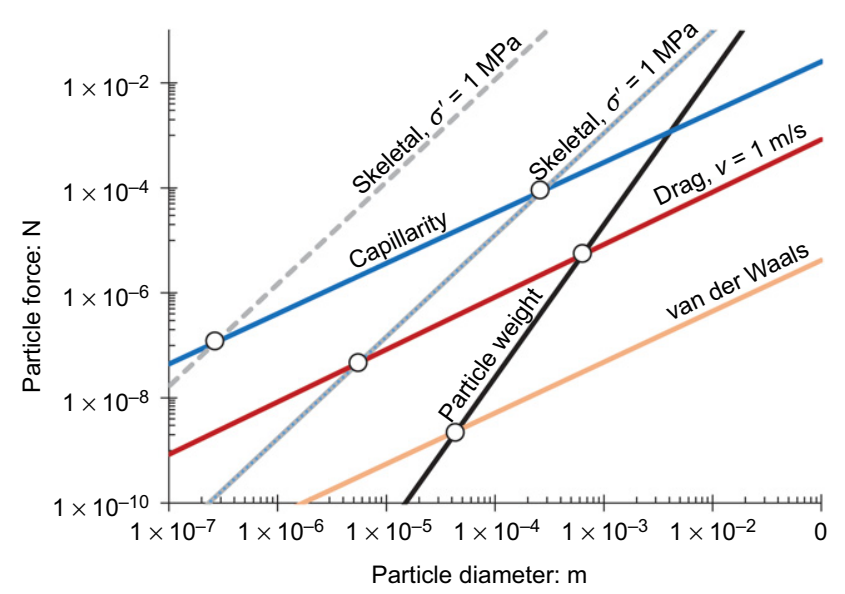

(a)

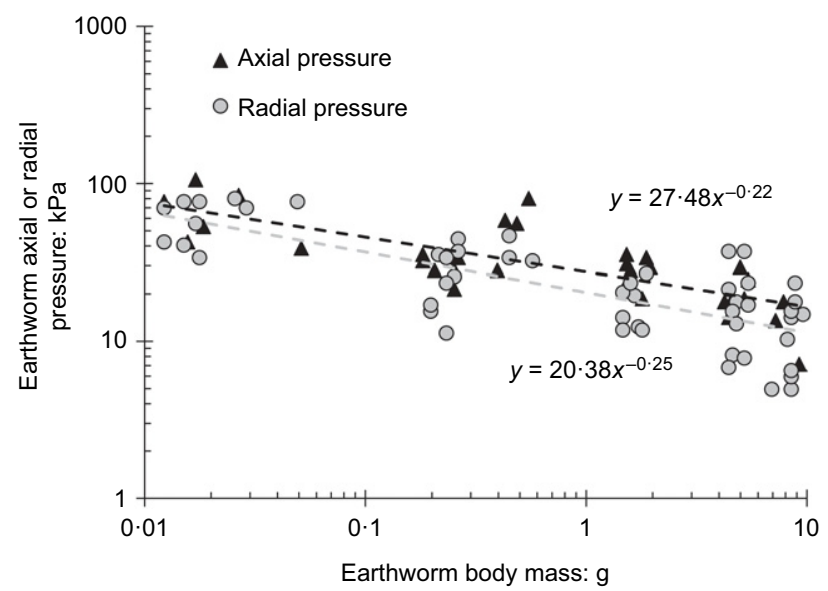

(b)

Fig. 2. Scaling with size and depth. (a) Analytical relationships for particle forces as a function of particle size where the blank markers indicate cross-points between forces (data from Santamarina (2001)); $\sigma^{\prime}=$ effective stress; $v=$ flow velocity. (b) Experimental measurements of axial and radial pressures applied by earthworms as a function of body mass (data from Quillin (2000)) 
performed to further understand these dependencies. A relevant example is the results by Quillin (2000) (Fig. 2(b)) relating to earthworm axial and radial burrowing pressures, which are shown to decrease as the body size is increased. These results suggest that the biological strategies that earthworms employ to apply burrowing forces become less efficient as they are upscaled.

Another important challenge in implementation of bio-inspired solutions is the difference in mechanical properties between biological and engineered materials (Table 1). Biological materials are typically more flexible, less stiff and weaker, and more anisotropic than engineering materials and they tend to be weaker in compression than in tension (Fratzl, 2007; Vogel, 2013). Some biological materials have received significant attention because they have properties that rival those of engineered materials. For instance, silk has been shown to have an ultimate tensile strength that is similar to steel and its toughness is much greater (Table 1). However, even these materials have important differences in properties in comparison to engineered materials. Specifically, the Young's modulus of silk is one to two orders of magnitude smaller than that of steel (Gosline et al., 1986; Altman et al., 2003).

Table 1. Mechanical properties of biological and engineered materials

\begin{tabular}{|c|c|c|}
\hline Material & $\begin{array}{l}\text { Ultimate tensile } \\
\text { strength: MPa }\end{array}$ & $\begin{array}{c}\text { Young's } \\
\text { modulus: GPa }\end{array}$ \\
\hline Collagen ${ }^{*}, \uparrow$ & $50-70$ & $0 \cdot 2-21 \cdot 5$ \\
\hline Cellulose* & 120 & $7 \cdot 5-11$ \\
\hline Chitin & 3 & 45 \\
\hline Resilin ${ }^{\S}$ & 3 & 0.002 \\
\hline Elastin ${ }^{\S}$ & 2 & 0.001 \\
\hline Bone $e^{\S, \|}$ & $88-132$ & $14 \cdot 6-25 \cdot 5$ \\
\hline Shell ${ }^{\Phi}$ & $140-170$ & $60-70$ \\
\hline Exoskeleton $^{* *, \dagger \dagger}$ & $13-30$ & $0 \cdot 5-0 \cdot 7$ \\
\hline Wood & $2-100$ & $0 \cdot 5-25 \cdot 0$ \\
\hline Keratin $^{\$ \$,\|\|}$ & $39-127$ & $0 \cdot 5-4 \cdot 3$ \\
\hline Silk & $500-972$ & $5-13$ \\
\hline Steel & $300-630$ & $200 \cdot 0$ \\
\hline Aluminium & 110 & $69 \cdot 0$ \\
\hline Concrete & $2-5$ & $14 \cdot 0-41 \cdot 0$ \\
\hline Kevlar & 3600 & 130 \\
\hline Soil & $0-1$ & $0 \cdot 1-1 \cdot 0$ \\
\hline $\begin{array}{l}\text { High-density polyethylene } \\
\text { (HDPE) }\end{array}$ & $35-58$ & $0 \cdot 5-1 \cdot 5$ \\
\hline Polyvinyl chloride (PVC) & 52 & $1 \cdot 5-3 \cdot 0$ \\
\hline
\end{tabular}

*van der Rijt et al. (2006); †Wenger et al. (2007); *Wainright et al. (1982); ${ }^{\S}$ Gosline et al. (1999); "Pal (2014); "Jackson et al. (1988);

${ }^{* *}$ Joffe et al. (1975); ${ }^{\dagger}$ Meyers et al. (2008); ${ }^{*}$ Wegst \& Ashby (2004); ${ }^{\$ \S}$ Tombolato et al. (2010); " "II Farran et al. (2009); " ${ }^{\top \uparrow}$ Altman et al., 2003.

\section{Bio-inspired design}

Abstraction is commonly employed in bio-inspired design to reframe the biological strategies in more general terms to aid in the translation towards engineering applications (e.g. Helms et al., 2009; Yen et al., 2011). Biological strategies can be cast in terms of forms, behaviours or principles (Mak \& Shu, 2004) (Fig. 3). In this context, forms refer to physical structures directly mimicking an organism, behaviours are analogies that reference the process without explicit translation of the physical shapes and principles describe at a more abstract level the underlying processes. More abstract levels of bio-inspiration are typically associated with more generalised solutions, which facilitate the translation to the spatial and temporal scales relevant to the engineering application (Mak \& Shu, 2004; DeJong et al., 2017). Fig. 3 provides examples of possible strategies inspired by snakeskin for soil-structure interfaces that mobilise directionally dependent friction and by earthworm burrowing for a self-burrowing probe. For the snakeskin-inspired surfaces, a direct translation would consist of replication of the shape and size of the scales, whereas a more abstract translation would consist of modifying the surface profile for passive resistances to be mobilised in the cranial direction (Martinez et al., 2020). For the self-burrowing probe, a direct translation would be mimicry of the earthworm shape and the sequence of motions involved in peristaltic locomotion and a more abstract translation would consist of using open-mode discontinuities or fractures to decrease the penetration resistance (Dorgan et al., 2007; Shin \& Santamarina, 2011).

Solution- and problem-driven design processes can be used to describe the types of bio-inspired design approaches that have been developed. The solution-driven design process starts with the biological solution abstraction (Fig. 4(a)) in which a biological strategy is identified. The strategy's principle is then extracted and the solution is reframed in more generalised terms to facilitate its translation to the engineering domain, as shown in Fig. 3. A search is then performed to identify an engineering problem that can be solved with this solution. Finally, the engineering problem is defined in general terms and the solution is applied towards that problem (Helms et al., 2009; Goel et al., 2014). In contrast, the problem-driven design process begins with an engineering problem, which must first be abstracted through reformulation and reframing to facilitate identification of biology-engineering analogies (Fig. 4(b)). Next, biological adaptations that provide a potential solution for the reframed problem are identified and evaluated. The last step is mapping and transfer, in which the underlying principle is extracted and applied to the engineering domain. $\mathrm{Fu}$ et al. (2014) and Fayemi et al. (2017) review bio-inspiration methods and tools for abstraction. DeJong et al. (2017) provide discussion and a specific example of bio-inspired design applied to geotechnical engineering.
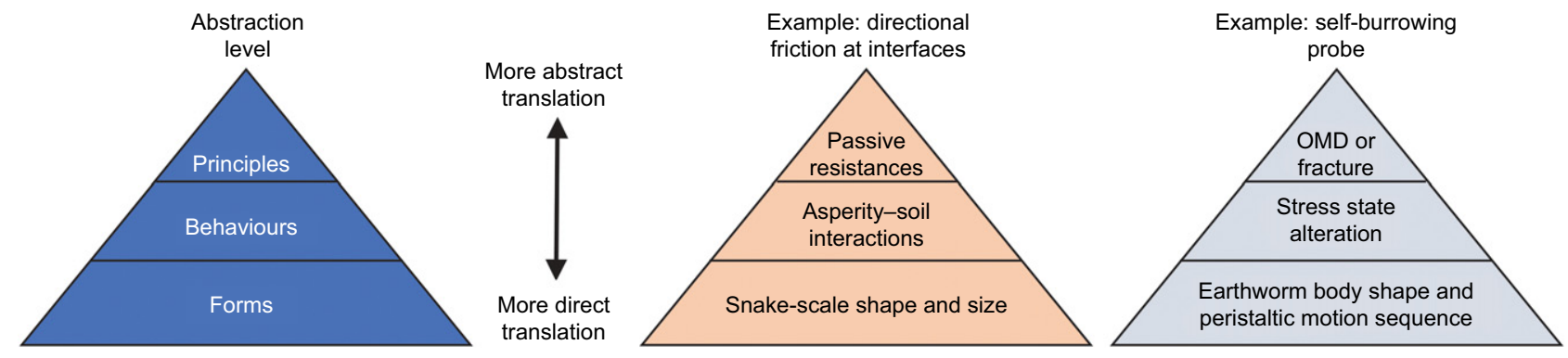

Fig. 3. Abstraction of bio-inspired strategies and examples for snakeskin-inspired soil-structure interfaces that mobilise directionally dependent friction and earthworm-inspired self-burrowing probe for site characterisation (OMD = open-mode discontinuity) 


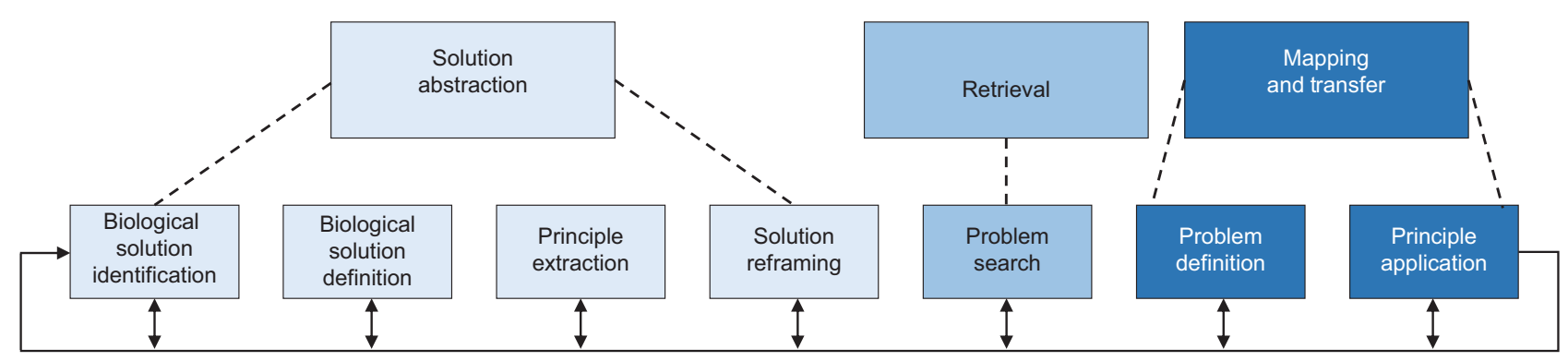

(a)

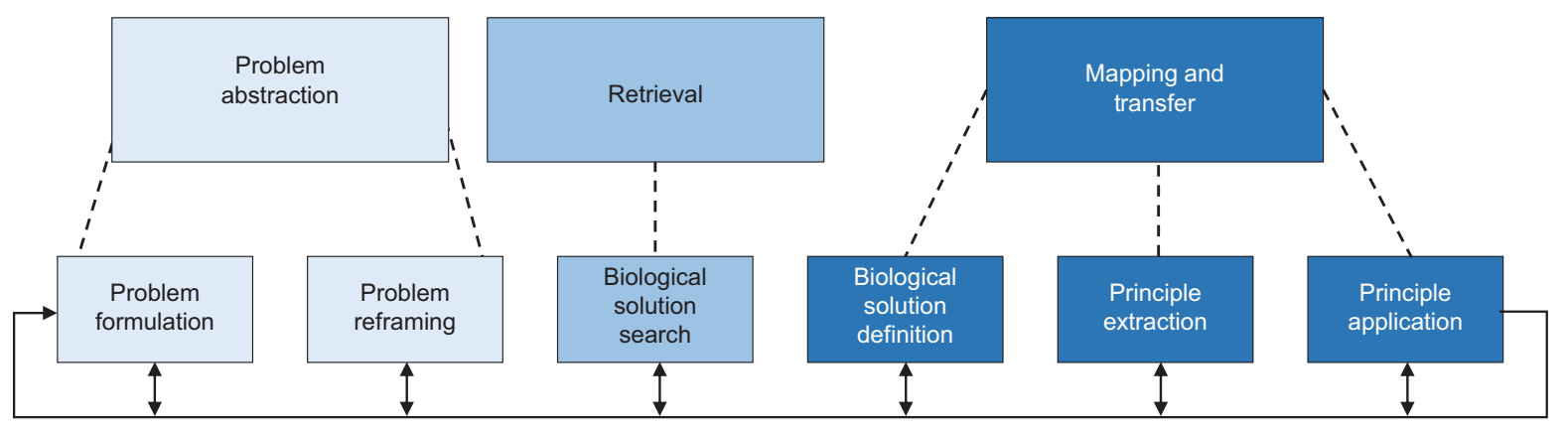

(b)

Fig. 4. (a) Solution-driven and (b) problem-driven bio-inspired design processes (redrawn from Helms et al. (2009), Yen et al. (2011), Goel et al. (2014) and DeJong et al. (2017))

\section{Tools for discovering biological strategies}

Biologists employ a variety of systems and tools to extract general principles from complex biological processes. For example, biological systems such as the musculoskeletal systems responsible for locomotion in animals are produced by non-linear and dynamically coupled interactions between the organism and its environment (Full \& Koditschek, 1999; Alexander, 2002; Biewener, 2003). In this case, allometry and similarity theory are used to evaluate the effect of size on processes or properties (Fig. 3(b)) (McMahon, 1973; Gunther, 1975; Ennos, 1993; Quillin, 2000; Che \& Dorgan, 2010). Descriptions of animal and plant morphology are facilitated by imaging technology such as X-ray computed tomography (CT), magnetic resonance imaging and laser and white light scanning (Huising \& Gomes Pereira, 1998; Dean et al., 2007; Wroe et al., 2008; Gignac \& Kley, 2014; Bot \& Irschick, 2019). For example, X-ray CT scans have revealed the skeleton shape of sand lance fishes, along with the kinematics they use to penetrate sandy soils rapidly to hide from predators (Bizarro et al., 2016) (Fig. 5(a)). Finite-element method (FEM) modelling, computational fluid dynamics (CFD), discrete-element method (DEM) modelling and resistive force theory (RFT) have also been employed to understand the underlying mechanisms behind morphological optimisation and the interactions between organisms and fluids and granular materials (Rayfield, 2007; Maladen et al., 2011; Li et al., 2013; Askari \& Kamrin, 2016; Davies et al., 2017). For example, DEM has been used to investigate the effect of void ratio and dilatancy in granular media and the body shape and kinematics in sandfish lizard locomotion (Fig. 5(b)) (Maladen et al., 2011).

Robotic models have been used in recent years to perform experimental investigations to discover new biological strategies and generate hypotheses about structure and function. This approach is typically referred to as 'robotics-inspired biology' and consists of the study of biological systems and models that reproduce behaviours consistent with empirical data (Gravish \& Lauder, 2018). Examples include investigations on the locomotion on granular media of sandfish

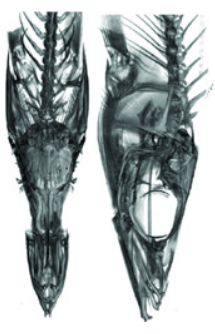

(a)

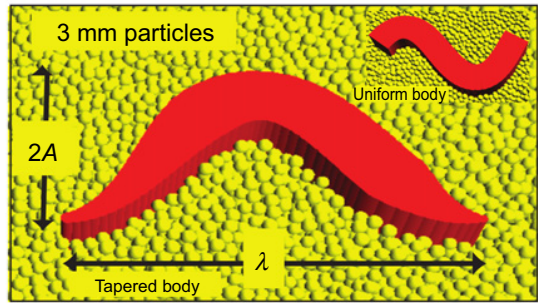

(b)
Fig. 5. Tools for discovering biological adaptations: (a) X-ray CT of sand lance skeleton; sand lance fishes penetrate sandy soils to hide from predators; (b) DEM modelling of sandfish lizard locomotion focused on the effect of the body wave amplitude (from Maladen $e t$ al. (2011))

lizards (Maladen et al., 2011), loggerhead hatchlings (Mazouchova et al., 2010), snakes (e.g. Marvi et al., 2014; Astley et al., 2015) and mudskipper fish (McInroe et al., 2016).

\section{ONGOING BIOLOGICAL AND BIO-INSPIRED INNOVATION RELEVANT TO GEOTECHNICS}

Important advances have been made with respect to understanding the interactions between living organisms and soils during burial, locomotion and growth. Some biological strategies have been successfully applied to the engineering domain, while others are still being investigated. Table 2 presents several geotechnical engineering applications where technologies, processes and/or materials have the potential to be advanced using bio-inspired solutions. The breadth of the examples listed highlights the extensive similarities that exist between how geotechnical engineered systems and biological organisms interact with soils. These examples also emphasise that understanding the biological strategies and fundamental geomechanical processes is 
Table 2. Summary of potential advances driven by bio-inspired geotechnics

\begin{tabular}{|c|c|c|}
\hline Applications & Technologies, processes and materials & Examples of possible sources of bio-inspiration \\
\hline $\begin{array}{l}\text { Soil penetration and } \\
\text { excavation }\end{array}$ & $\begin{array}{l}\text { Sensor deployment, tunnelling and installation of } \\
\text { underground, utilities, foundations and soil } \\
\text { anchors }\end{array}$ & $\begin{array}{l}\text { Earth and marine worm, clam and caecilian } \\
\text { burrowing, fish sand diving, plant root growth }\end{array}$ \\
\hline $\begin{array}{l}\text { Foundation and } \\
\text { anchoring elements }\end{array}$ & $\begin{array}{l}\text { Improved designs for increased capacity and } \\
\text { reduction in material and energy use }\end{array}$ & $\begin{array}{l}\text { Tree root system architecture, directionally dependent } \\
\text { friction at snakeskin, plant root growth }\end{array}$ \\
\hline Ground improvement & $\begin{array}{l}\text { Improvement and stabilisation of large sites with } \\
\text { energy-efficient technologies }\end{array}$ & $\begin{array}{l}\text { Tree and grass root system architecture, marine worm } \\
\text { sediment digestion }\end{array}$ \\
\hline Materials & $\begin{array}{l}\text { New materials and configurations for improved } \\
\text { mechanical, hydraulic and thermal performance }\end{array}$ & $\begin{array}{l}\text { Silk hierarchical structure, abalone shell composite } \\
\text { structure, denticle stiffness gradient }\end{array}$ \\
\hline $\begin{array}{l}\text { Slope stabilisation and } \\
\text { erosion mitigation }\end{array}$ & $\begin{array}{l}\text { Protection of natural and engineered slopes and } \\
\text { coastal and fluvial areas }\end{array}$ & Grass and tree root architecture, oyster beds \\
\hline $\begin{array}{l}\text { Earth moving and } \\
\text { manipulation }\end{array}$ & $\begin{array}{l}\text { Earth-moving machines and processes with } \\
\text { increases in energy efficiency and productivity }\end{array}$ & $\begin{array}{l}\text { Ant, crab and shrimp excavation and earth-moving } \\
\text { processes, earthworm and plant root bioturbation }\end{array}$ \\
\hline $\begin{array}{l}\text { Renewable energy } \\
\text { generation and } \\
\text { regulation }\end{array}$ & $\begin{array}{l}\text { Harvesting and storage of solar, wind, tidal and } \\
\text { geothermal energy }\end{array}$ & $\begin{array}{l}\text { Thermal transport in insect nests and animal burrows, } \\
\text { plant carbon storage }\end{array}$ \\
\hline $\begin{array}{l}\text { Transport of water and } \\
\text { contaminants }\end{array}$ & $\begin{array}{l}\text { Design of hydraulic barriers and containment } \\
\text { systems, ground, fluid extraction and injection }\end{array}$ & $\begin{array}{l}\text { Plant evapotranspiration, leaf venations, animal } \\
\text { circulatory systems }\end{array}$ \\
\hline Filtration & $\begin{array}{l}\text { Prevention of fines migration and their detrimental } \\
\text { effects (e.g. piping, suffusion) }\end{array}$ & Semi-permeable membranes in biological tissue \\
\hline Locomotion and mobility & $\begin{array}{l}\text { Exploration of challenging environments (e.g. loose } \\
\text { sand, soft clays, extraterrestrial bodies) }\end{array}$ & Snake, gecko, insect and fish locomotion \\
\hline
\end{tabular}

necessary to realise these and other bio-inspired solutions. This section provides examples of interdisciplinary investigations in the applications of soil penetration and excavation, foundation and anchoring elements, earth moving, energy regulation, transport of water and slope stabilisation.

\section{Burrowing, excavation and soil penetration}

Research in biology has revealed some of the mechanisms that animals and plants use to penetrate and excavate different kinds of soils. These adaptations are highly energy efficient, presumably exponentially more so than current engineering practices (e.g. Soga, 2011). Thus, their translation to the geotechnical engineering domain could provide new advances for infrastructure construction, site characterisation, tunnelling and excavation.

Marine and earth worms, clams and other animals. The mechanical work necessary to penetrate soil and extend a burrow depends on the failure mechanism of the soil, which varies with soil type, depth (Fig. 6(a); Dorgan, 2015), soil stiffness and toughness and organism size (Che \& Dorgan, 2010; Dorgan, 2015; Ruiz et al., 2015). In cohesive soils, burrowing at shallow depths can be achieved through plastic rearrangement of soil grains and aggregates. At greater depths, organisms such as worms, clams and plant roots alternate radial expansion and axial elongation motions to extend burrows by fracture propagation and deformation-induced softening (Trueman, 1968; Abdalla et al., 1969; Greacen \& Oh, 1972; Dorgan et al., 2005, 2007). This is typically achieved by applying radial stresses against the burrow walls, either through expansion of a body section near the burrow tip or through movement of mouthparts, which results in effective stress relaxation at the burrow tip (referred to as an open-mode discontinuity by Shin \& Santamarina (2011)). In non-cohesive soils, burrowing at shallow depths can be enabled by 'sand fluidisation,' a process in which rapid shearing of soil induces a local flow failure due to soil contraction or generation of excess pore pressures. This process is used by several worms, shrimps, crabs and vertebrate organisms, including sandfish lizards and ocellated skinks (Trueman, 1970; Maladen et al., 2011;
Sharpe et al., 2015; McInroe et al., 2018). At greater depths in sands, burrowers use similar behaviours as in cohesive sediments: they employ a dual-anchor system to apply normal forces to burrow walls with different regions of the body (Dorgan, 2018). Rather than causing fractures, these forces are likely to locally compact the surrounding soil and induce effective stress relaxation ahead of the tip. In addition, the radial expansion against the burrow walls increases the pressure against the organism's body, which provides an anchor to generate propulsion to penetrate the soil in the form of friction and bearing capacity (Trueman, 1968; Summers \& O'Reilly, 1997; Dorgan, 2018). Organisms such as razor clams and other bivalves also soften the soil through fluid injection and dynamic expansion and contraction of their shell to increase local pore pressures (Trueman, 1968; Winter et al., 2012).

DEM simulations and laboratory experiments relating to bio-inspired self-burrowing probes for site characterisation have highlighted key aspects that enable penetration using the dual-anchor mechanism (Cortes \& John, 2018; Huang \& Tao, 2018; Khosravi et al., 2018; Chen et al., 2020, 2021; Huang \& Tao, 2020). Radial expansion of a probe section develops anchorage forces and relaxes the contact forces ahead of the probe's tip, facilitating subsequent penetration (Fig. 6(b)). Cavity expansion simulations have been used to assess the upscaling potential of a dual-anchor mechanism in sandy, silty and clayey soils at different depths (Martinez et al., 2020). Results indicate that a probe consisting of a radially expanded anchor and a penetrating tip would require an anchor with a length of $2 \cdot 0$ to $4 \cdot 5$ times the tip diameter to generate sufficient anchorage forces, which is on the order of aspect ratios (length-to-diameter ratio, $L / D$ ) of various razor clam species (Fig. 6(c)). Other research has focused on developing prototypes for sensor deployment applications. For instance, Tao et al. (2019) and Huang et al. (2020) developed robot prototypes capable of burrowing out by employing an elongation-shortening mechanism inspired by razor clam locomotion. The authors showed that the robot's performance in dry sand depends on the relative density (Fig. 5(d)), the period of the expansion-contraction cycles and the soil-robot interface frictional interactions. Ortiz et al. (2019) developed a marine worm-inspired soft robot that employs two strategies: bi-directional bending of the 


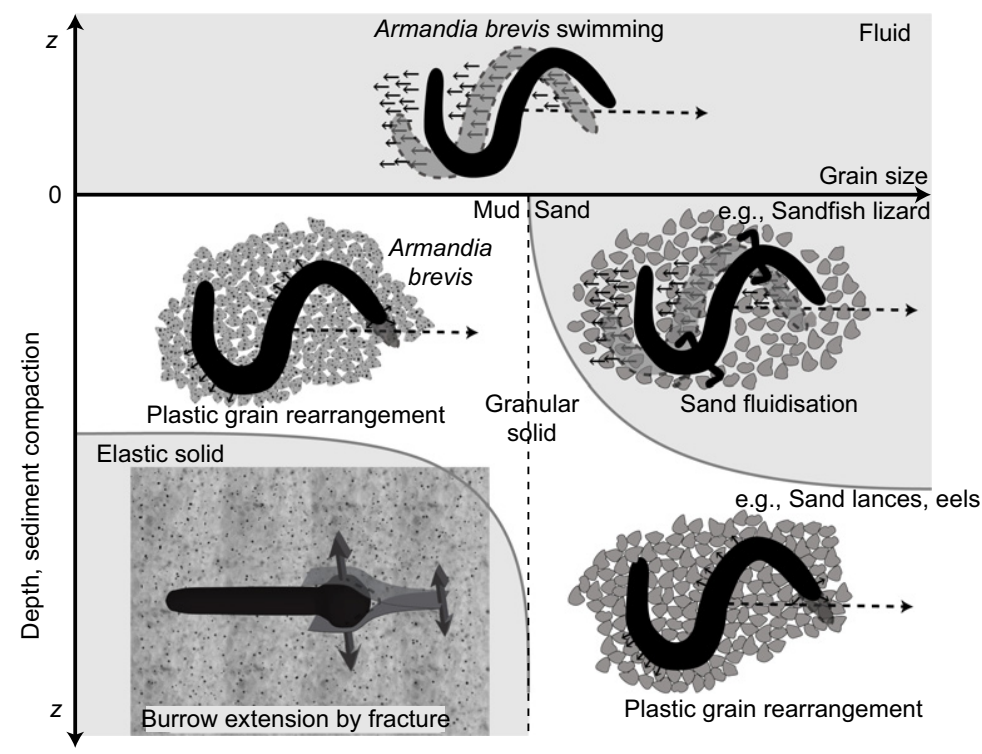

(a)

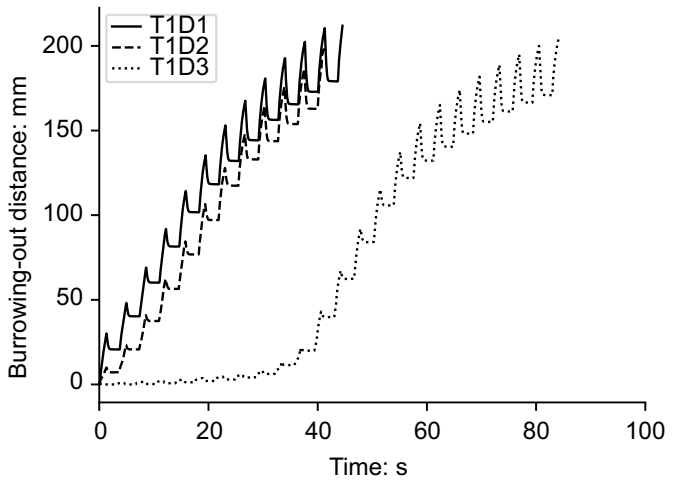

(d)

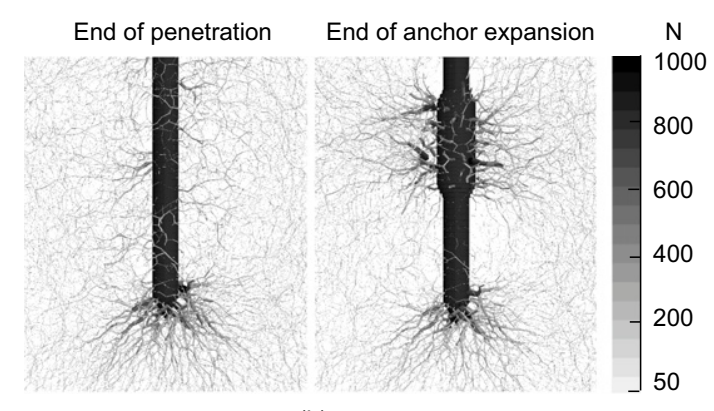

(b)

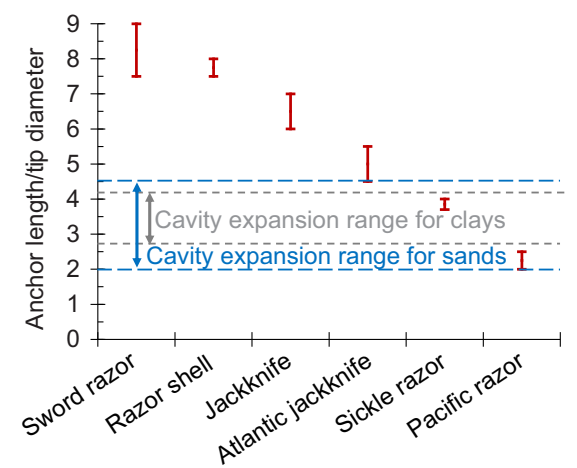

(c)

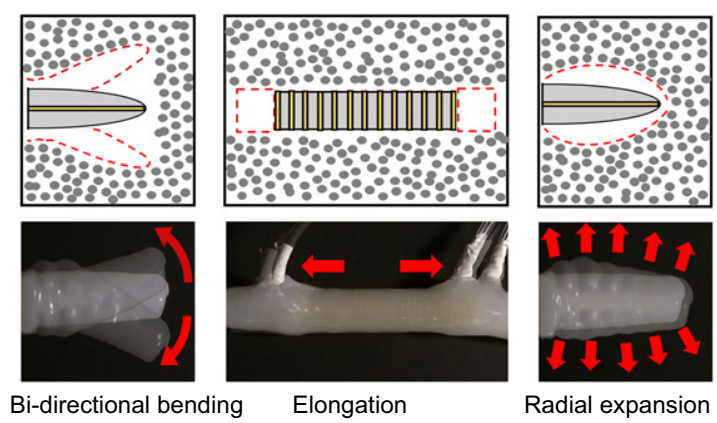

(e)

Fig. 6. Bio-inspired burrowing. (a) Schematic representation of strategies employed by burrowing organisms as a function of depth and grain size (from Dorgan (2015)). (b) Force chain map from DEM simulation of bio-inspired probe during self-burrowing showing mobilisation of tip resistance and anchor reaction (data from Chen $e t$ al. (2021)). (c) Comparison of length-to-diameter ratios for self-burrowing obtained from cavity expansion analyses for depths between $5 \mathrm{~m}$ and $40 \mathrm{~m}$, showing agreement with dimensions of various clam species (data from Martinez et al. (2020)). (d) Burrowing-out curves of bio-inspired actuator showing the effect of sand relative density (D1, D2 and D3 correspond to different sand relative densities, data from Tao et al. (2019)). (e) Actuation strategies consisting of lateral head movement and body elongation employed by a burrowing soft robot (redrawn from Ortiz et al. (2019))

head to remove and loosen soil and radial expansion of a body section to provide anchorage (Fig. 6(e)). Use of these techniques in constant-displacement experiments reduced the penetration resistance by up to $50 \%$ and allowed a tethered prototype to move horizontally through granular media.

Ants. Ants efficiently excavate stable nest structures in different soil types. For instance, Soga (2011) provided comparisons of the energy efficiency of the excavation using tunnel-boring machines (TBMs) with that of ant tunnelling. TBMs were reported to have efficiencies between two and four orders of magnitude lower than ant tunnelling $\left(1.7 \times 10^{7}\right.$ to $4.4 \times 10^{8} \mathrm{~J} / \mathrm{m}^{3}$ in rock and sand for the former and $1.2 \times 10^{4}$ to $7.9 \times 10^{5} \mathrm{~J} / \mathrm{m}^{3}$ in sand for the latter). Field and laboratory studies have shown that ant excavation habits and performance, and resulting nest architecture, change with soil type and conditions. X-ray CT observations on fire ant colonies showed that nest depth depends on particle size and water content (Monaenkova et al., 2015). The most stable tunnels were excavated at intermediate water contents (Fig. 7(a)), implying that the increasing strength provided by the capillary forces allowed for creation of more stable tunnels. Yamamoto et al. (2019) performed two-dimensional and three-dimensional (3D) experiments on monolayer and multilayer soil deposits. Changes in particle size and density did not significantly influence tunnel diameter, but excavation rates and volume of excavated soil were greater in soils with lower density and smaller particle sizes. Espinoza \& Santamarina (2010) revealed the role of different interparticle forces on the excavation ability of ants and the stability of ant tunnels. Analytical results show that the ant mandible pulling force is expected to be greater than the combined particle weight and electrical and capillary forces for particles smaller than fine gravels (Fig. 7(b)). Fig. 7(c) presents a synthesis of the results, showing the effect of grain size and degree of saturation on the tunnel stability and excavation performance of ants. Antlions and wormlions are also efficient at excavating in 


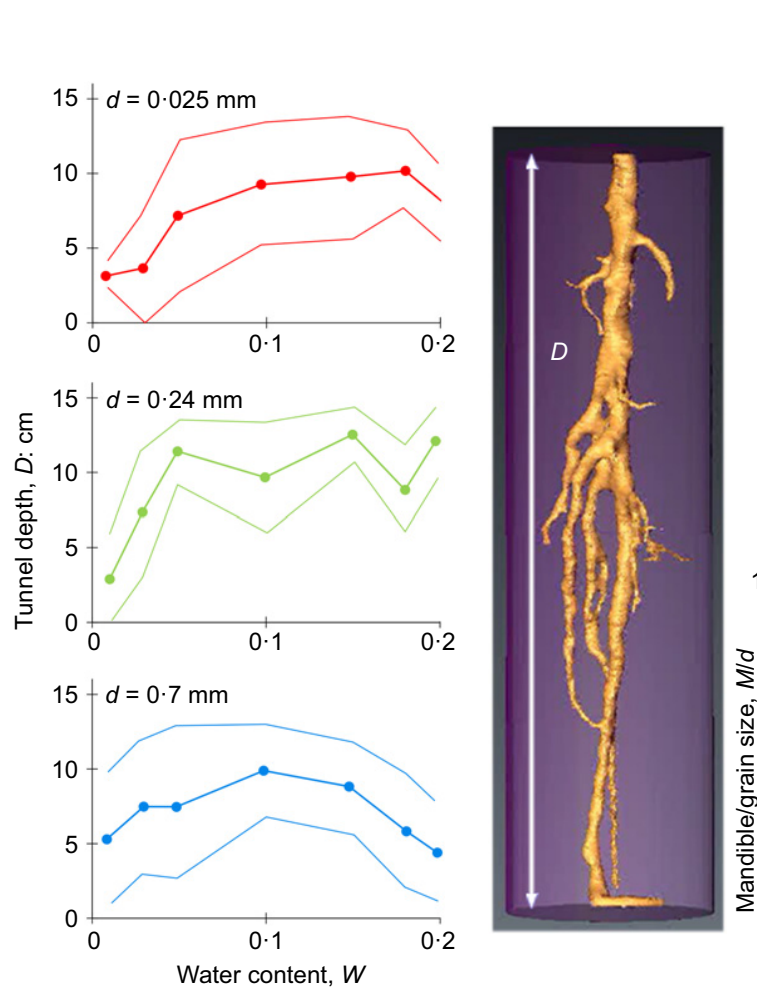

(a)

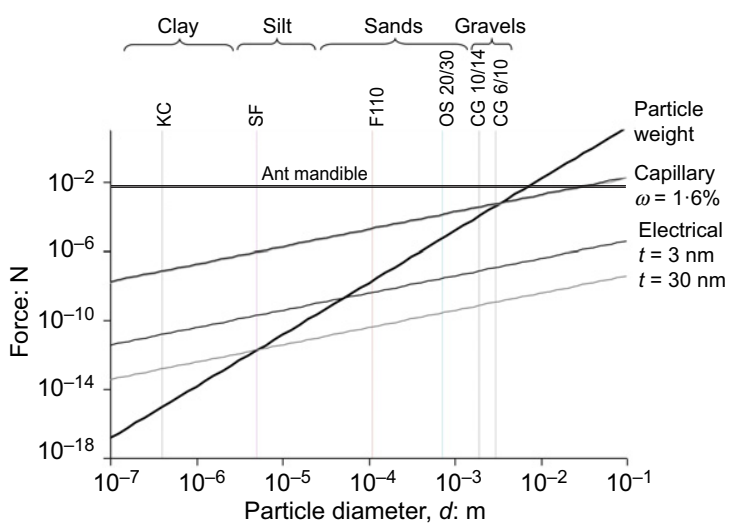

(b)

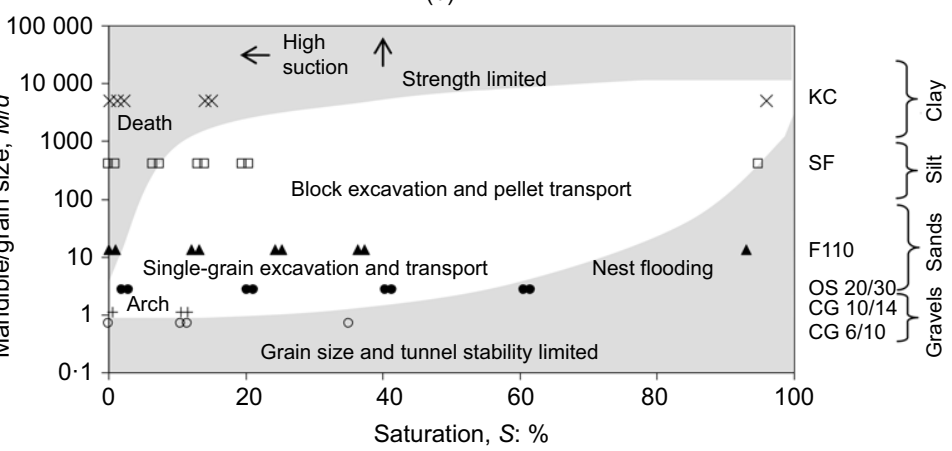

(c)

Fig. 7. Ant tunnel excavation and stability: (a) effect of particle size and water content on the depth of fire ant nests, showing an optimal water content for tunnel stability $(D=$ nest depth, $d=$ mean particle size, $W=$ water content; adapted from Monaenkova $e t$ al. $(2015)$ ); (b) interparticle forces as a function of particle size $(t=$ distance between particles, $\omega=$ water content) (adapted from Espinoza $\&$ Santamarina $(2010)$; (c) geometrical and geomechanical control of ants' digging behaviour highlighting restrictions imposed by the limited ant mandible force and tunnel instability ( $M=$ mandible size, $d=$ mean particle size) (adapted from Espinoza \& Santamarina (2010))

both coarse- and fine-grained soils. These animals dig cone-shaped traps to hunt prey; antlions use a spiral digging strategy whereas wormlions use a central digging strategy (Tuculescu et al., 1975; Franks et al., 2019). Research has shown that the angles of the antlion and wormlion traps are close to the angle of repose and that the soil within the trap slopes is close to the critical state (Botz et al., 2003, Büsse et al., 2020). The instability of these slopes, along with sand throwing by the predators, creates avalanches that make prey slide and fall to the bottom of the trap.

Plant and tree roots. Soil conditions affect the growth, establishment and natural selection of plants. Plants, in turn, influence soil properties such as chemical composition and internal structure, and can contribute to increased erosion and landslide resistance. Plant and tree roots grow in many different conditions, from clays and soils rich in organic materials (e.g. crops, cypress trees) to sandy substrates (e.g. palm trees and dune grasses) to rocky terrains (e.g. juniper trees). The characteristics of the root system, as well as its interactions with the soil, including the penetration resistances, root architecture and anchorage capacity, are a function of the plant species and soil and environmental conditions (e.g. Grime, 1977; van Noordwijk \& De Willigen, 1987; Bengough \& Mullins, 1990; Bengough \& McKenzie, 1997; Barthélémy \& Caraglio, 2007).

Savioli et al. (2014) performed FEM simulations of root growth in non-cohesive soil. These simulations monitored the radial effective stresses and volumetric strains while a root-shaped cavity was expanded (Fig. 8(a)). Radial expansion increased the radial effective stress along the sides of the root (shown in cooler shades) and decreased the stress at the root tip (shown in warmer shades). While volumetric strains were dilative overall, the dilation zone was largest at the root tip. These results suggest that the relaxation of stresses and decrease in density at the tip may facilitate soil penetration, especially in stiff and strong soils, in agreement with Shin \& Santamarina (2011).

The influence of the soil properties and condition on the growth of a root system has been largely investigated in the field of plant science (e.g. Bengough \& Mullins, 1990; Atwell, 1993). However, the root growth process alters the in situ state of stresses, fabric and moisture conditions, which in turn can influence the mechanical behaviour of the soil. Anselmucci et al. (2021) performed in vivo X-ray CT of seeds growing in coarse and fine sand of varying density (Fig. 8(b)). Their X-ray CT data analysed with digital image correlation (DIC) measured the evolution of the soil strain field and showed that the sand grains are mainly displaced in the same direction as root elongation for distances equivalent to two mean particle diameters.

During growth, plant roots perform oscillatory, semicircular movements called circumnutations (Mullen et al., 1998). Although the role of circumnutation in plant root growth is still debated, recent findings by Taylor et al. (2021) indicate that circumnutation is critical for seedling establishment in rocky soil because they facilitate growth past obstacles. Del Dottore et al. (2018) hypothesised that these movements can decrease penetration resistance. The authors validated this hypothesis experimentally by comparing the resistances mobilised and work needed for straight, vertical penetration and penetration performed with circumnutations by an artificial probe. Results show that circumnutations decrease penetration resistance and work across a range of 

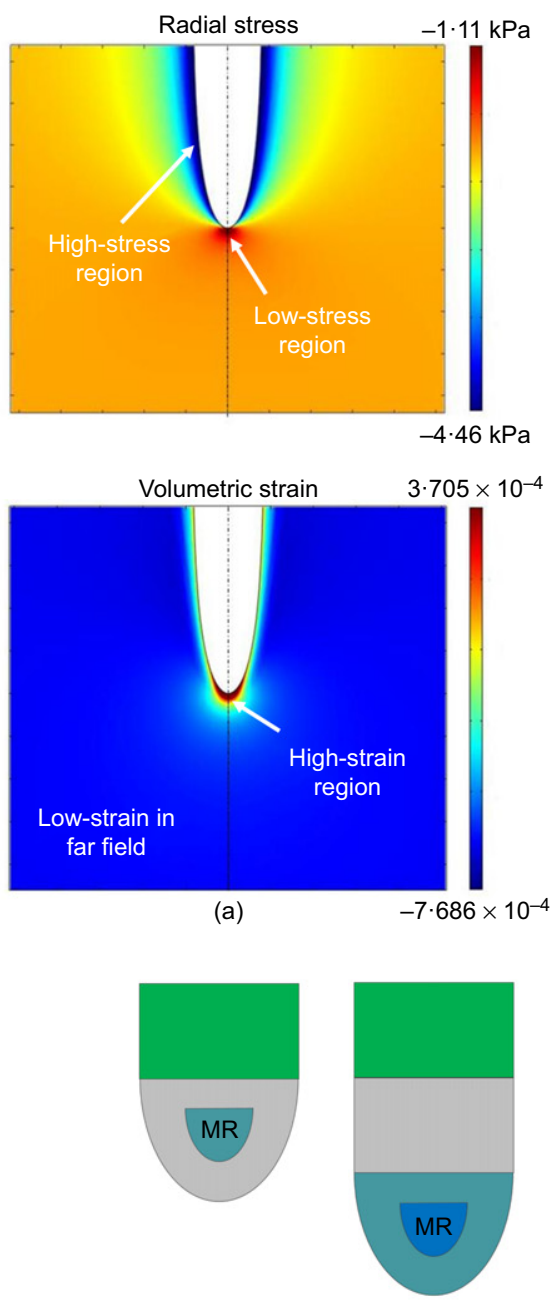

(d)
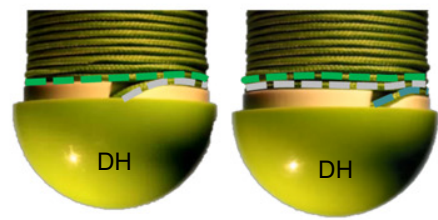

(e)

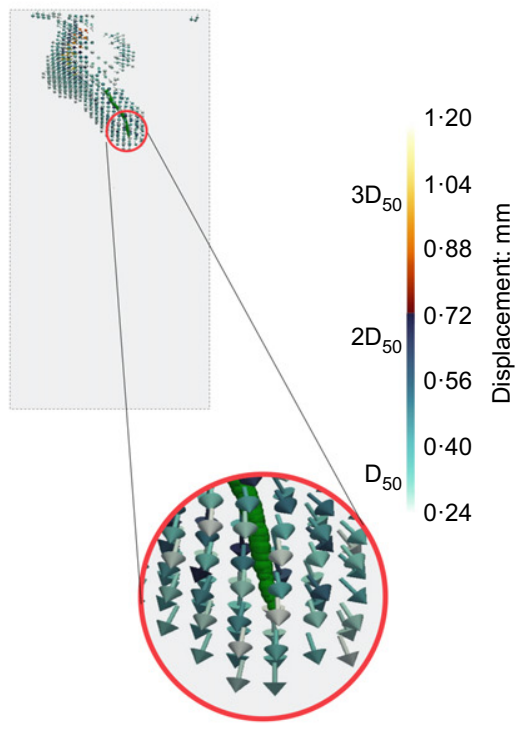

(b)

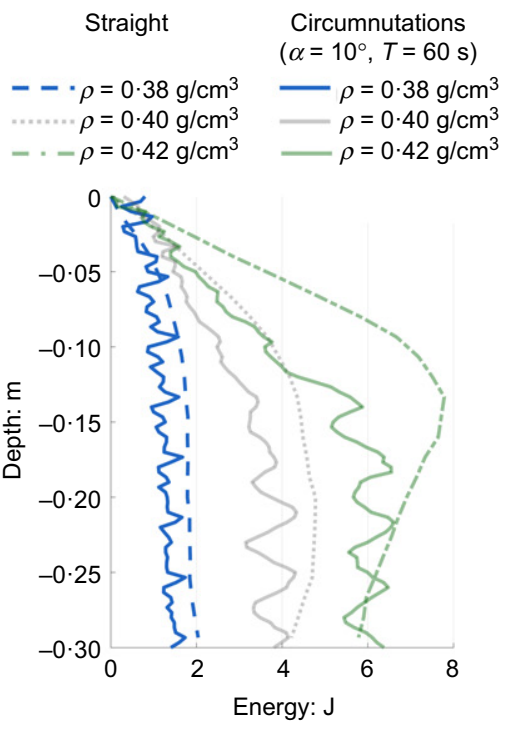

(c)
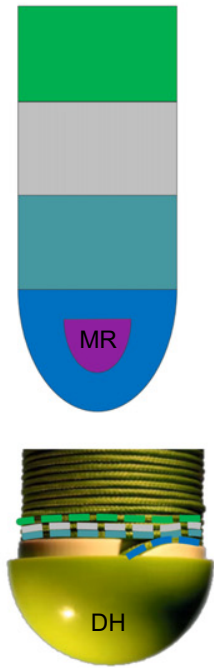

(1)

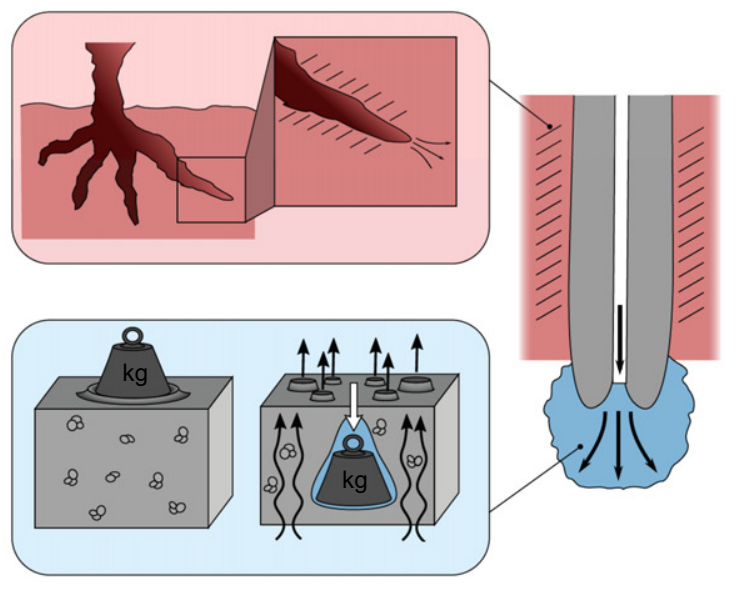

(f)

Fig. 8. Soil penetration by plant roots. (a) Numerical results of radial root growth showing relaxation of radial stresses (warm colours) and dilation (warmer colours) at root tip (from Savioli et al. (2014)). (b) X-ray CT scan of root system growing in sand showing particle displacements (from Anselmucci et al. (2021)). (c) Comparison of work during straight and circumnutative penetration showing greater efficiency of circumnutative penetration $(\rho=$ soil density, $\alpha=$ angle amplitude of circumnutations, $T=$ period of circumnutations, from Del Dottore $e t$ al . (2018)). (d) Schematic diagram showing root growth process, indicating successive cells growing in the meristematic region (MR) and shifting over time into the mature region (from Sadeghi et al. (2014)). (e) Root-like device for soil penetration. As the deposition head (DH) rotates, it deposits a filament around the outer surface (from Sadeghi et al. (2014)). (f) Root-inspired burrowing device that combines root tip extension and soil fluidisation to decrease penetration resistances (from Naclerio et al. (2018)). A full-colour version of this figure can be found on the ICE Virtual Library (www.icevirtuallibrary.com)

soil densities (Fig. 8(c)). Prototypes of burrowing robots have focused on decreasing the penetration resistance to enable deeper soundings and more efficient operations (e.g. Del Dottore et al., 2018). Sadeghi et al. (2014) developed a device inspired by root growth in which new material is added behind the tip as it advances. This mimics the root growth process, where cells split and slough as they mature (Fig. 8(d)). This significantly reduces frictional resistance along the root sides, leaving only the penetration resistance to overcome, and can result in a $70 \%$ decrease in energy consumption compared to conventional penetration. Fig. 8(e) presents a series of images of this root-inspired robot. Naclerio et al. (2018) developed a soft self-burrowing robot that combines the bio-inspired principle of plant root growth by way of tip extension with air-induced fluidisation (Fig. 8(f)). The authors report a reduction in penetration resistance of $10 \times$ relative to vertical pseudo-static penetration and demonstrate $50 \mathrm{~cm}$ deep growth into real sand in less than $20 \mathrm{~s}$.

Fish. Many fish bury themselves to ambush prey and evade predators. Some fish, like the sand lance, burrow by diving head-first into the substrate while undulating their bodies. Researchers have not observed sand fluidisation to reduce 
penetration resistances. Instead, Bizarro et al. (2016) proposed that the spacing of the scale bands interacts with the grain size of the substrate to produce reduced frictional forces between the fish and the sand. In flatfish, body size and undulation frequency affect burial performance (McKee et al., 2016). These authors developed a physical model of a flatfish to isolate the effect of undulation on burial speed. Their results suggest there is an optimal range of undulation frequency $(5-10 \mathrm{~Hz})$ that allows for the most efficient burial, suggesting that generation of excess pore water pressures due to cyclic loading occurs. Pacific sandfish have been hypothesised to use a modified two-phase respiratory pump to force water into the substrate during burial to liquefy it and decrease burial resistances (Macdonald et al., 2014).

\section{Directional interface friction}

Load transfer across soil-structure interfaces plays an important role in the capacity and efficiency of many geotechnical engineering applications. Some applications benefit from maximising interface shear resistance (e.g. axially loaded deep foundations, soil nails), whereas others benefit from minimising shear resistance (e.g. pile driving, soil sampling). Directionally dependent frictional resistances are present in the biological strategies employed by different organisms, such as the leaves of some trees and grasses, the paws and tongues of certain mammals and birds, and the skin of several mammals and reptiles. Surfaces that mobilise different amounts of shear resistance depending on the direction of loading, referred to as directional friction or frictional anisotropy, can provide new solutions to geotechnical applications in which loads are applied in different directions during the installation process and service life.

Snakes. Although snakes lack limbs, they move efficiently in a variety of environments including sand dunes, trees, forest litter, prairie grasslands and oceans. Their ventral scales are aligned transversely along their underbelly (Fig. 9(a)) and the frictional interactions between the scales and the substrate control the snake's locomotive performance. Several studies have shown that snakes rely on directional friction for locomotion, where the 'cranial' friction coefficient is greater than the 'caudal' friction coefficient (Fig. 9(b)). Gray \& Lissmann (1950) measured the friction coefficient between dead snakes and various textured surfaces, obtaining values of 1.22 in the cranial direction and 0.49 in the caudal direction for sandpaper. Marvi et al. (2013) also measured friction coefficients between $40 \%$ and $250 \%$ greater in the cranial than caudal direction for three snake species (Fig. 9(c)). In addition to the asymmetric geometry of the scales, nano-scale features called denticles within each scale (Fig. 9(d)) contribute to frictional anisotropy at a smaller scale (e.g. Hazel et al., 1999; Baum et al., 2014). A comparative study by Rieser et al. (2021) indicates that the structure of the denticles directly influences the locomotor performance of snakes, such as sand-inhabiting sidewinders.

Researchers have investigated the development of direction-dependent friction resistances at soil-structure interfaces for applications such as deep foundations, soil anchors and soil nails and landfill liner systems. Martinez et al. (2019), Stutz et al. (2019), O’Hara \& Martinez (2020) and Huang \& Martinez (2020) performed monotonic and cyclic interface shear tests between sand and surfaces inspired by $3 \mathrm{D}$ scans of snakeskin, showing that shearing in the cranial direction mobilised larger interface shear resistances than shearing in the caudal direction. Differences of from 25 to $90 \%$ were observed during monotonic and cyclic shearing (Figs 10(a) and 10(b), respectively). Huang \& Martinez (2021) examined the effect of normal effective stress, overconsolidation ratio and shearing velocity on the interface shear behaviour between clay and snakeskin-inspired surfaces and concluded that the response has a smaller direction dependence as compared to the interfaces with sand. Martinez et al. (2018), O'Hara \& Martinez (2020) and Martinez \& O'Hara (2021) also investigated the effect of snakeskin-inspired surface texturing on the performance of model piles during centrifuge load tests. The results indicate a difference in installation forces of $48 \%$ and pullout forces of $128 \%$, where loading in the cranial direction consistently led to greater frictional resistances (Fig. 10(c)).

\section{Load transfer and anchorage}

The foundation and anchorage systems used by the geotechnical engineering industry are mostly composed of linear elements, primarily due to ease of construction and the industry's familiarity with these types of elements. Advances in the understanding of the mechanisms that contribute to capacity generation and in techniques to construct non-linear elements efficiently may lead to improvements in the infrastructure construction sector.

Tree root systems. Research on the anchorage mechanisms of root systems has been performed in the fields of plant biology, soil science and geotechnical engineering. This research has highlighted several factors that contribute to

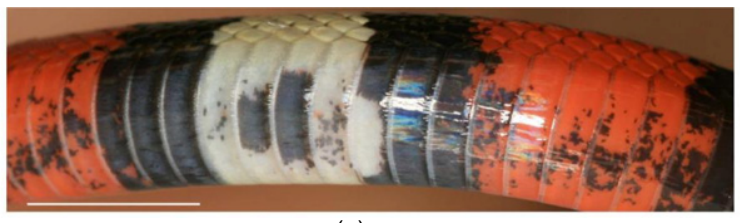

(a)

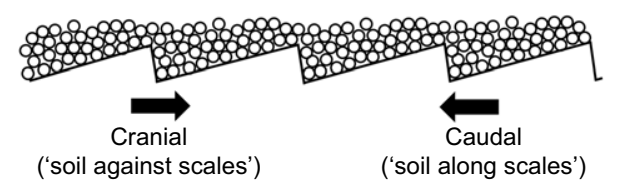

(b)

\begin{tabular}{|l|c|c|c|}
\hline Species & $\mu_{\text {cranial }}$ & $\mu_{\text {caudal }}$ & $\mu_{\text {cranial }} / \mu_{\text {caudal }}$ \\
\hline Boa constrictor $^{*}$ & 0.42 & 0.30 & 1.40 \\
\hline Dumeril's boa $^{*}$ & 0.06 & 0.017 & 3.53 \\
\hline Gaboon viper $^{*}$ & 0.32 & 0.12 & 2.67 \\
\hline Grass snake $^{\dagger}$ & 1.22 & 0.49 & 2.49 \\
\hline${ }^{*}$ Marvi et al. (2013)
\end{tabular}
*Marvi et al. (2013)
†Gray \& Lissman (1950)

(c)

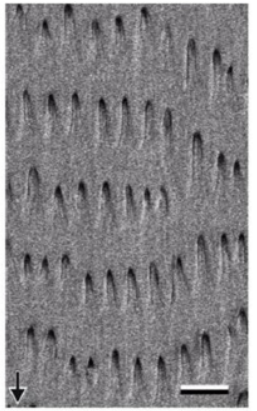

(d)

Fig. 9. Biological strategies for directional friction in snakeskin: (a) photograph of ventral scales of a milk snake (scale bar corresponds to 1 cm, from Hu et al. (2009)); (b) schematic diagram of cranial and caudal shearing directions; (c) friction coefficient $(\mu)$ measurements for different snakes in the cranial and caudal directions; (d) scanning electron microscopy images of denticles within a snake scale (arrow points towards snake's tail and scale bar is $2 \mu \mathrm{m}$ long, from Baum et al. (2014)) 


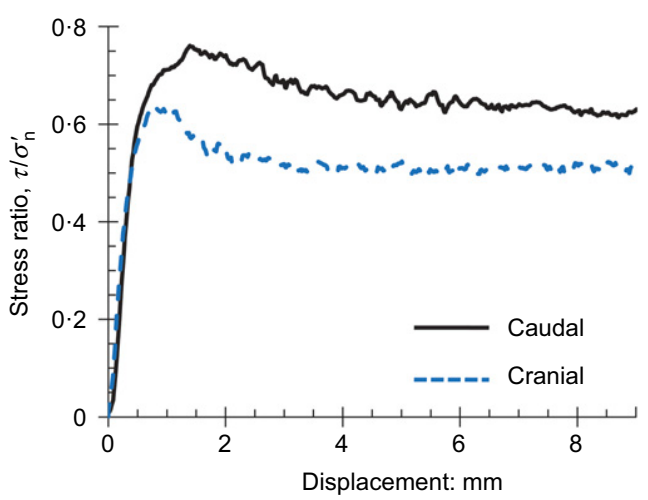

(a)

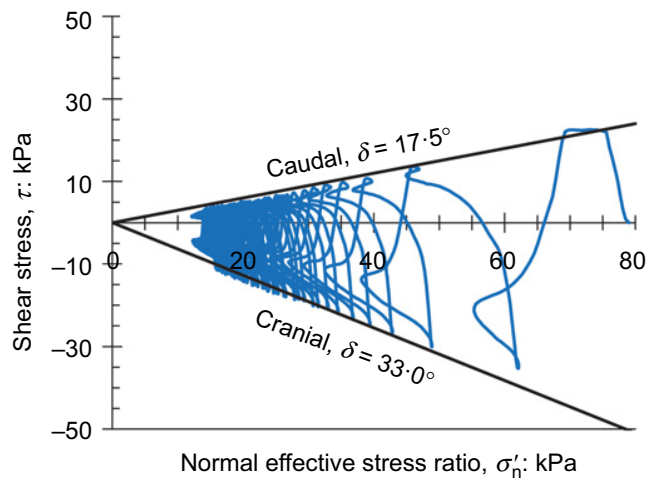

(b)

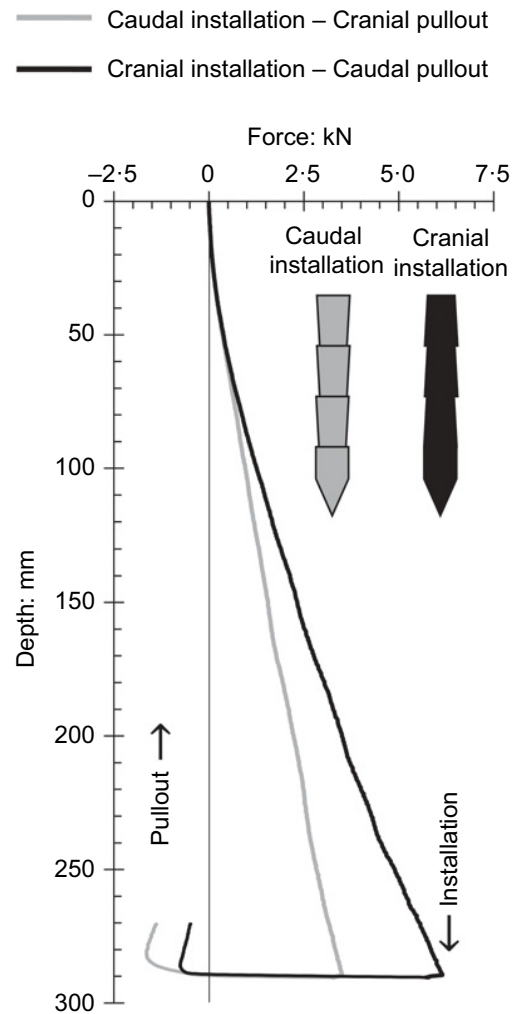

(c)

Fig. 10. Directional friction in load transfer across soil-structure interfaces. (a) Monotonic and (b) cyclic interface shear tests on snakeskin-inspired surface and sand showing the larger stress ratio and friction angle mobilised during cranial shearing (data from $O$ 'Hara \& Martinez (2020)); $\delta$, interface friction angle. (c) Centrifuge load tests on snakeskin-inspired piles highlighting the greater forces mobilised during cranial installation and pullout (data from O'Hara \& Martinez (2020))

anchorage capacity and load transfer, including architecture (i.e. level of branching and branching angle), root stiffness and soil shear strength (e.g. Coutts, 1983; Gray \& Ohashi, 1983; Ennos, 1993; Stokes et al., 2000; Fourcaud et al., 2003; Gregory, 2006; Hamza et al., 2007; Mickovski et al., 2007). Investigations focused on developing bio-inspired technologies for foundation and anchorage systems have involved field, centrifuge and laboratory experiments and numerical simulations. For instance, Burrall et al. (2020) performed field vertical pullout tests on fruit trees with three different rootstock types (Lovell, Marianna and Myrobalan), which differ in their architectural characteristics. The results, shown in Fig. 11(a), indicate that the rootstock type had an important influence on the initial stiffness, peak capacity and softening of the pullout force-vertical displacement curves. The pullout performance of the root systems was calculated to be one to two orders of magnitude more efficient in terms of material use than business-as-usual alternatives such as micropiles and spread footings. Laboratory tests by Mallett et al. (2018) provided further insight into the effect of root architecture on the soil deformation around root analogues in sand. X-ray CT scans reveal the formation of shear bands within the sand whose location depends on the root internal angle (Fig. 11(b)). The geometry of the sand slip surface was generally conical in shape; however, its size and orientation changed with the root angle. Aleali et al. (2020) applied a multifaceted bio-inspiration approach to generate design ideas for deep foundations with greater shaft resistance than conventional cylindrical piles. Their design incorporates biological strategies such as a flexible but incompressible core, a longitudinally split shell that allows lateral expansion for anchorage and lateral root-type anchoring elements. FE modelling of the bio-inspired laterally expansive pile shows significant advantages in terms of greater confining pressure and load-carrying capacity compared to conventional piles.

\section{Mass and thermal transport}

Slope stability and the movement of water and heat are geotechnical engineering challenges that can be aggravated by changing environmental conditions, such as rainfall and drought. In addition, distribution networks for resources represent an optimisation problem subjected to multiple constraints. Understanding and applying biological strategies to develop new solutions for the transport of mass and heat, accounting for their effects on soil response where applicable, can lead to the development of safer and more resilient and sustainable engineering solutions.

Plants. Trees and plants take up moisture from the soil through their roots, which then evaporates from their leaves (evapotranspiration). This water removal from soil increases the soil suction (e.g. Blight, 2003; Hemmati et al., 2012), and is sometimes referred to as 'hydraulic reinforcement'. Researchers have quantified the suction magnitude and the influence zone size for different plant and tree species, concluding that vegetation increases both the suction magnitude developed during drying as well as that maintained during wetting (e.g. $\mathrm{Ng}$ et al., 2013). Other researchers have shown that vegetation can alter the soil-water retention curve (Leung et al., 2015a) and reduce the hydraulic conductivity and infiltration rate in soils (e.g. Leung et al., 2015b). Engineering analyses have confirmed the beneficial effects of vegetation on slope stability (Gray \& Sotir, 1996). For instance, Switala \& Wu (2018) showed through FEM simulations that slope displacements during rainfall were 

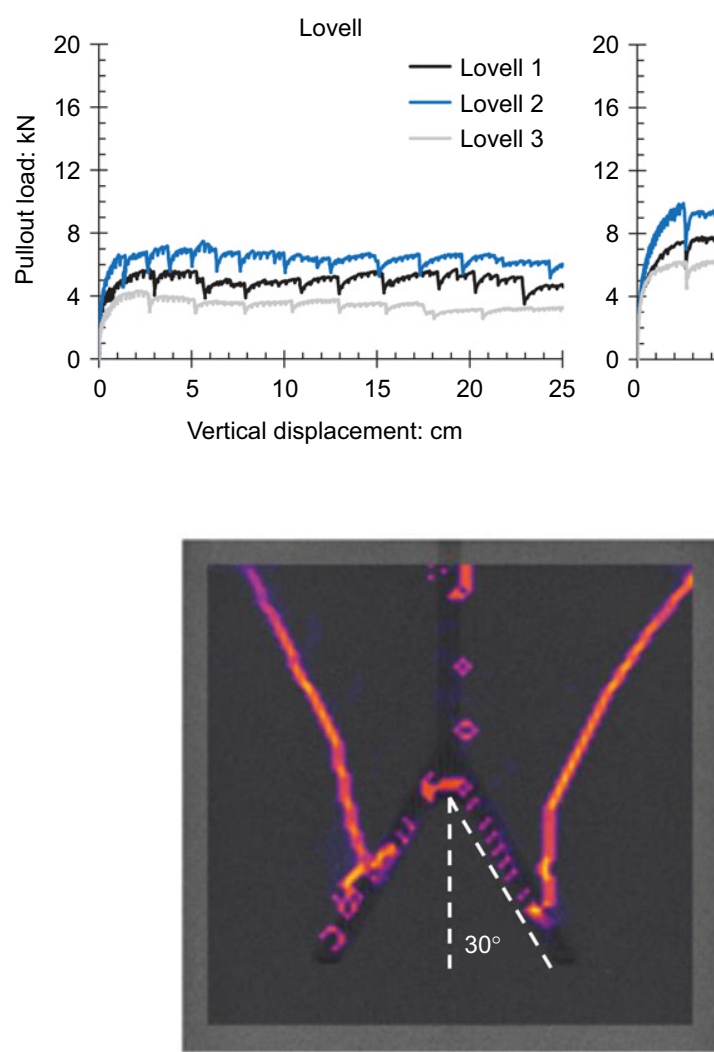

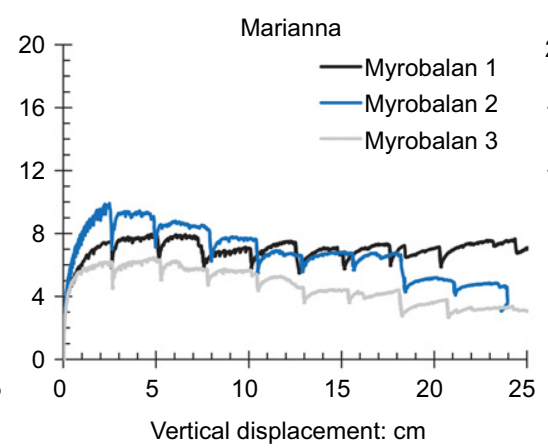

(a)
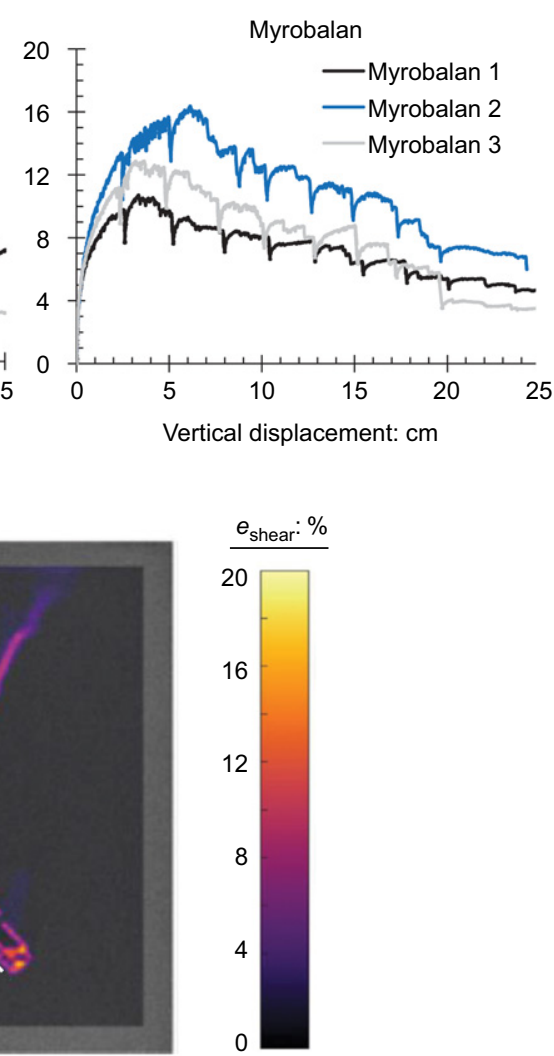

(b)

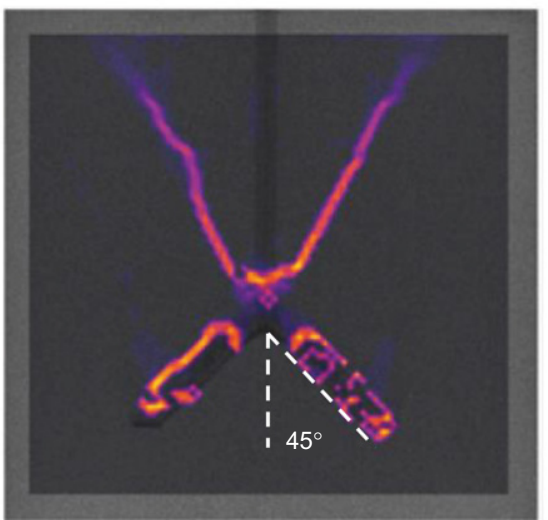

Fig. 11. Anchorage of natural and analogue root systems: (a) force-displacement curves during vertical pullout test of Lovell, Marianna and Myrobalan rootstocks where the Myrobalan rootstocks mobilise the largest pullout forces (data from Burrall et al. (2020)); (b) shear strain ( $\left.e_{\text {shear }}\right)$ maps within soil from X-ray CT scans during vertical pullout tests on root analogues where the location of the shear band depends on the root branching angle (from Mallett et al. (2018))

significantly smaller on vegetated slopes than on bare slopes (Fig. 12(a)). In addition, the authors showed that slope horizontal displacements were smaller when both mechanical reinforcement by roots and increase in suction by evapotranspiration were considered (Fig. 12(b)).

Leaf venations. The problem of connecting a central node to a set of spatially scattered points is common to many natural and artificial systems of all scales and levels of complexity. In engineering, this is common in distribution networks (e.g. public transportation, water and gas distribution). Patino-Ramirez \& Arson (2020) evaluated a leaf venation (LV) algorithm for designing bio-inspired infrastructure transportation networks employing Runion's algorithm (Runions et al., 2005). This algorithm generates venation systems that grow out a stem in a finite domain that contains a given distribution of auxin sources. Auxin is a growth hormone that dictates the direction of growth of venation segments. Patino-Ramirez \& Arson (2020) modelled the city of Atlanta metropolitan area with the stem representing the intersection of two Metropolitan Atlanta Rapid Transit Authority (MARTA) metro lines and the auxin sources representing population centroids (Fig. 12(c)). Results indicate that leaf-inspired models can perform similarly to or better than computer-intensive optimisation algorithms in terms of network cost and service performance, which could facilitate the design of engineering transportation and resource distribution networks.

Termite mounds. The nest and mound superstructures built by colonies of fungus-farming termites (Fig. 12(d)) are efficient at controlling internal ventilation, which helps regulate internal heat and humidity (Turner \& Soar, 2008; Katariya et al., 2018; Vesala et al., 2019). The mound is porous across nano-, micro- and macro-scales, with the tunnel structure within the mound constituting the macro-scale pores (Turner, 2005). Air is brought up through the nest as a result of diurnal temperature oscillations, where it mixes with spent air and gases such as carbon dioxide, then rises into the mound where it is dissipated through the mound material to the atmosphere (King et al., 2015). Turner \& Soar (2008) indicated that gas exchange with the atmosphere is controlled by convection in the main tunnel, mixed convection and diffusion in the millimetre-scale tunnels and diffusion through the micro- and nano-pores. Relative to the atmospheric temperature, the mound's internal temperature is from 10 to $15^{\circ} \mathrm{C}$ warmer during the night and from 10 to $15^{\circ} \mathrm{C}$ cooler during the day largely due to the large thermal capacity of the soil surrounding the nest (Turner \& Soar, 2008; also Bardunius and Lingwall, personal communication, 2020). The mound is constructed by the termites from locally available soils around the nest (Jouquet et al., 2004), where termites employ only the fine fractions of soil at moisture contents between the liquid and plastic limits (Kandasami et al., 2016). In addition, organic material in the soil is essential for effective cohesion of transported soil pellets (Zachariah et al., 2017).

\section{CLOSURE: OPPORTUNITIES AND CHALLENGES}

Important advances have been made in the last decade to understand the strategies that biological organisms use to interact with soils to accomplish functions such as burrowing and anchorage. Examples include strategies used by marine worms and earthworms, clams, ants, fish, snakes, tree and 


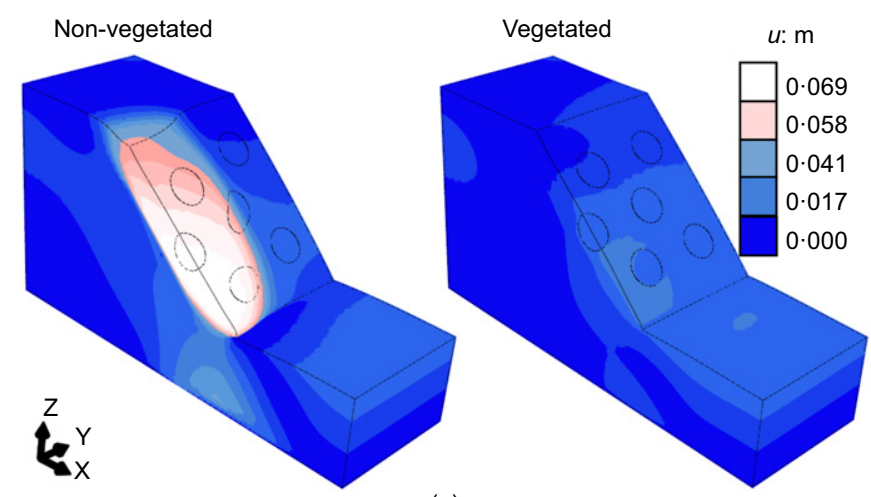

(a)

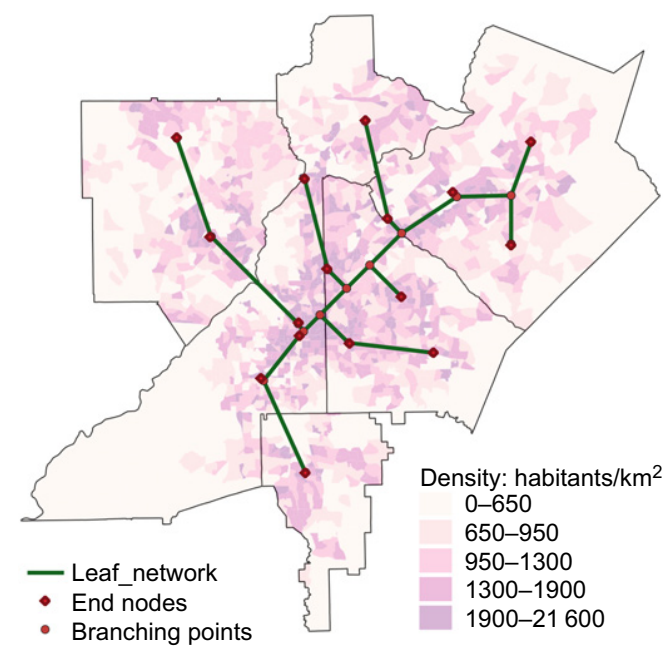

(c)

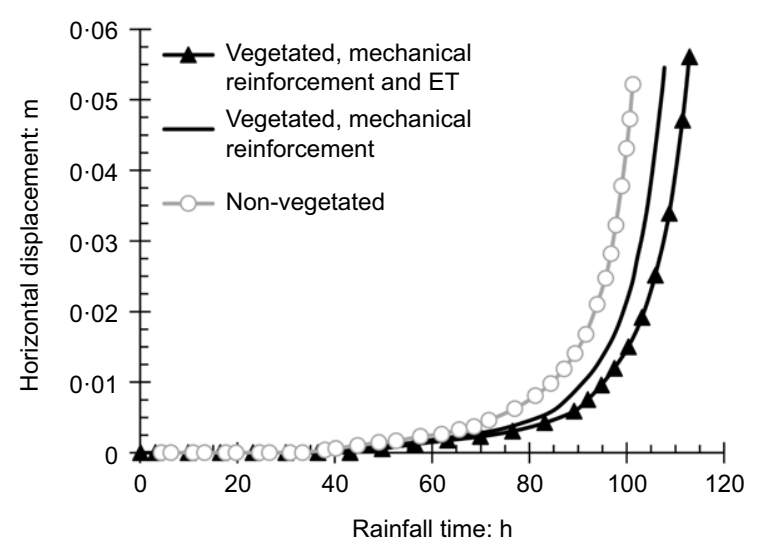

(b)
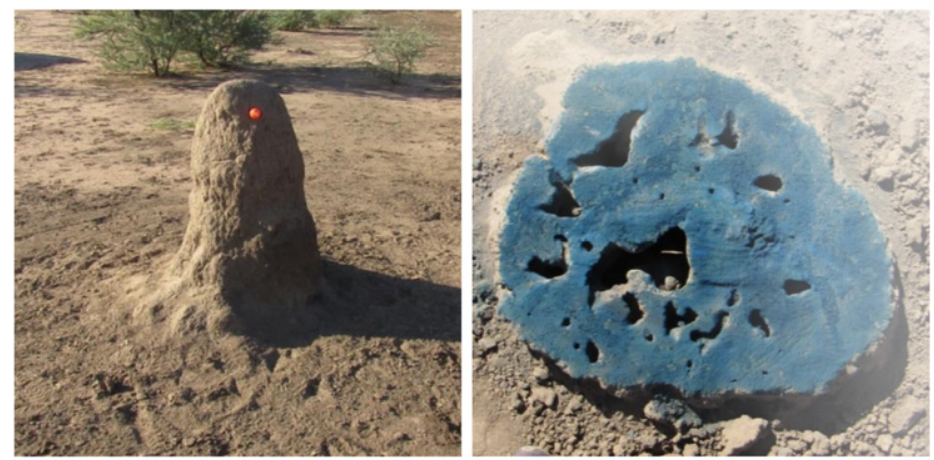

(d)

Fig. 12. Mass and thermal transport. (a) Contours of horizontal displacements, $u$, after $100 \mathrm{~h}$ of rainfall obtained from FEM simulation of a non-vegetated slope and a slope with mechanical root reinforcement and evapotranspiration. (b) Comparison of slope horizontal displacements for non-vegetated and vegetated cases where mechanical reinforcement and evapotranspiration reduce the slope movements (from Switala \& Wu (2018)). (c) Leaf venation (LV) network connecting 15 discrete population centroids in Metro Atlanta (from Patino-Ramirez \& Arson (2020)). (d) Photograph of Macrotermes michaelseni termite mound and cross-section in Namibia showing multi-scale porosity (height of mound is about $5 \mathrm{ft}(1.52 \mathrm{~m}))$

plant roots, leaf venations and termite mounds. This biology-based understanding is being leveraged to inspire new solutions for geotechnical applications such as foundations, soil anchors and nails, soil penetration and excavation, site characterisation, sensor deployment, slope stability and both mass and thermal transport.

The strategies employed by living organisms to interact with soils have evolved in highly constrained environments, which require them to prioritise efficiency while coping with multiple demands simultaneously. These strategies have been 'vetted' by the process of natural selection; thus, they are multifunctional, redundant, robust and efficient. However, the development of bio-inspired solutions requires assessment of the differences between biological and engineering environments, such as the larger sizes and greater stresses relevant to geotechnical engineering applications. This is important at a fundamental level because the forces that govern soil behaviour depend on the particle size and confining stress, and because biological processes have a strong dependency on the organism's size.

The implementation of bio-inspired solutions towards geotechnical practice requires collaborations and crosstraining between researchers, practitioners, engineers and biologists. The early involvement of practitioners is critical to identify industry needs and viable solution paths while cross-training between engineers and biologists is necessary for the discovery of biological strategies and development of bio-inspired technologies. These interdisciplinary teams need to have basic disciplinary knowledge and understanding in geomechanics, geotechnical practice, biology and bio-inspired design. This emphasises the need for educational developments at university and professional levels. This shared background will enable researchers to develop sound hypotheses, designers to understand the technical aspects and applicability of new technologies, contractors to complete construction successfully and verify performance, regulators to understand how new technologies fit within existing regulations and owners to recognise the potential benefits of investing and adopting these bio-inspired solutions.

\section{ACKNOWLEDGEMENTS}

This paper is the product of the 1st International Workshop on Bio-Inspired Geotechnics, held in May 2019 in Pacific Grove, California, USA. The 1st International Workshop on Bio-inspired Geotechnics was funded in part by the US National Science Foundation under grant no. CMMI-1821029 and the NSF-funded Center for Biomediated and Bioinspired Geotechnics (CBBG) under grant no. EEC-1449501. Any opinions, findings and conclusions or recommendations expressed in these materials are those of the author(s) and do not necessarily reflect the views of the National Science Foundation. 


\section{REFERENCES}

Abdalla, A. M., Hettiaratchi, D. R. P. \& Reece, A. R. (1969). The mechanics of root growth in granular media. J. Agric. Engng Res. 14, No. 3, 236-248.

Aleali, S. A., Bandini, P. \& Newtson, C. M. (2020). Multifaceted bioinspiration for improving the shaft resistance of deep foundations. J. Bionic Engng 17, No. 5, 1059-1074, https://doi. org/10.1007/s42235-020-0076-6.

Alexander, R. M. (2002). Principles of animal locomotion. Princeton, NJ, USA: Princeton University Press.

Alting, L., Kimura, F., Hansen, H. N. \& Bissacco, G. (2003). Micro engineering. Ann. CIRP 52, No. 2, 635-657, https://doi.org/10. 1016/S0007-8506(07)60208-X52/2:635-657.

Altman, G. H., Diaz, F., Jakuba, C., Calabro, T., Horan, R. L., Chen, J., Lu, H., Richmond, J. \& Kaplan, D. L. (2003). Silk-based biomaterials. Biomaterials 24, No. 3, 401-416, https://doi.org/10.1016/S0142-9612(02)00353-8.

Amatya, B. L., Soga, K., Bourne-Webb, P. J., Amis, T. \& Laloui, L. (2012). Thermo-mechanical behavior of energy piles. Géotechnique 62, No. 6, 503-519, https://doi.org/10.1680/geot. 10.P.116.

Anselmucci, F., Andò, E., Viggiani, G., Lenoir, N., Peyroux, R., Arson, C. \& Sibille, L. (2021). Use of x-ray tomography to investigate soil deformation around growing roots. Géotechnique Lett. 11, No. 1, 96-102, https://doi.org/10.1680/jgele.20.00114.

Askari, H. \& Kamrin, K. (2016). Intrusion rheology in grains and other flowable materials. Nat. Mater. 15, 274-1279, https://doi. org/10.1038/nmat4727.

Astley, H. C., Gong, C., Dai, J., Travers, M., Serrano, M. M., Vela, P. A., Choset, H., Mendelson, J. R., Hu, D. L. \& Goldman, D. I. (2015). Modulation of orthogonal body waves enables high maneuverability in sidewinding locomotion. Proc. Natn. Acad. Sci. 112, No. 19, 6200-6205, https://doi.org/ 10.1073/pnas.1418965112.

Atwell, B. J. (1993). Response of roots to mechanical impedance. Environ. Expl Bot. 33, No. 1, 27-40, https://doi.org/10.1016/ 0098-8472(93)90053-I.

Autumn, K., Sitti, M., Liang, Y. A., Peattie, A. M., Hansen, W. R., Sponberg, S., Kenny, T. W., Fearing, R., Israelachvili, J. N. \& Full, R. J. (2002). Evidence of van der Waals adhesion in gecko setae. Proc. Natn. Acad. Sci. 99, No. 19, 12252-12256, https:// doi.org/10.1073/pnas. 192252799.

Barthélémy, D. \& Caraglio, Y. (2007). Plant architecture: a dynamic, multilevel and comprehensive approach to plant form, structure and ontogeny. Ann. Bot. 99, No. 3, 375-407.

Baum, M. J., Kovalev, A. E., Michels, J. \& Gorb, S. N. (2014). Anisotropic friction of the ventral scales in the snake Lampropeltis getula californiae. Tribol. Lett. 54, No. 2, 139-150, https://doi.org/10.1007/s11249-014-0319-y.

Bengough, A. G. \& McKenzie, B. M. (1997). Sloughing of root cap cells decreases the frictional resistance to maize (Zea mays L.) root growth. J. Expl Bot. 48, No. 4, 885-893, https://doi.org/ $10.1093 / \mathrm{jxb} / 48.4 .885$.

Bengough, A. G. \& Mullins, C. E. (1990). Mechanical impedance to root growth: a review of experimental techniques and root growth responses. J. Soil Sci. 41, No. 3, 341-458, https://doi.org/ 10.1111/j.1365-2389.1990.tb00070.x.

Biewener, A. (2003). Animal locomotion. Oxford, UK: Oxford University Press.

Bizarro, J. J., Peterson, A. N., Blaine, J. M., Balaban, J. P., Greene, H. G. \& Summers, A. P. (2016). Burrowing behavior, habitat and functional morphology of the Pacific sand lance (Ammodytes personatus). NOAA Fish. Bull. 114, No. 4, 445-460.

Blight, G. E. (2003). The vadose-zone soil-water balance and transpiration rates of vegetation. Géotechnique 53, No. 1, 55-64, https://doi.org/10.1680/geot.2003.53.1.55.

Bot, J. A. \& Irschick, D. J. (2019). Using 3D photogrammetry to create open-access models of live animals: $2 \mathrm{D}$ and $3 \mathrm{D}$ software solutions. In $3 D / V R$ in the academic library: emerging practices and trends (eds J. Grayburn, Z. Lischer-Katz, K. Golubiewski-Davis and V. Ikeshoji-Orlati), pp. 54-72. Alexandria, VA, USA: Council on Library and Information Resources (CLIR).

Botz, J. T., Loudon, C., Barger, J. B., Olafsen, J. S. \& Steeples, D. W. (2003). Effects of slope and particle size on ant locomotion: implications for choice of substrate by antlions. J. Kansas Ent. Soc. 76, No. 3, 426-435.
Brandl, H. (2006). Energy foundations and other thermo-active ground structures. Géotechnique 56, No. 2, 81-122, https://doi.org/10.1680/geot.2006.56.2.81.

Burrall, M., DeJong, J. T., Martinez, A. \& Wilson, D. W. (2020). Vertical pullout tests of orchard trees for bio-inspired engineering of anchorage and foundation systems. Bioinspir. Biomim. 16, No. 1, https://doi.org/10.1088/17483190/abb414.

Büsse, S., Büscher, T. H., Heepe, L., Gorb, S. N. \& Stutz, H. H. (2020). Sand throwing in a pit-building antlion larva from a soil mechanical perspective. bioRxiv, https://doi.org/10.1101/2020. 11.25.398073.

Che, J. \& Dorgan, K. M. (2010). It's tough to be small: dependence of burrowing kinematics on body size. J. Expl Biol. 213, No. 8, $1241-1250$.

Chen, Y., Khosravi, A., Martinez, A., DeJong, J. T. \& Wilson, D. W. (2020). Analysis of the self-penetration process of a bio-inspired in situ testing probe. In Geo-congress 2020: biogeotechnics (eds E. Kavazajian, J. P. Hambleton, R. Makhnenko and A. S. Budge), Geotechnical Special Publication 320 , pp. 224-232. Reston, VA, USA: American Society of Civil Engineers.

Chen, Y., Khosravi, A., Martinez, A. \& DeJong, J. T. (2021). Modeling the self-penetration process of a bio-inspired probe in granular soils. Bioinspir. Biomim. in press, https://doi.org/ 10.1088/1748-3190/abf46e.

Cortes, D. D. \& John, S. (2018). Earthworm-inspired soil penetration. Proceedings of biomediated and bioinspired geotechnics (B2G) conference, Atlanta, GA, USA.

Coutts, M. P. (1983). Root architecture and tree stability. Plant Soil 71, 171-188, https://doi.org/10.1007/BF02182653.

Danjon, F., Barker, D. H., Drexhage, M. \& Stokes, A. (2008). Using three-dimensional plant root architecture in models of shallowslope stability. Ann. Bot. 101, No. 8, 1281-1293, https://doi.org/ 10.1093/aob/mcm 199 .

Davies, T. G., Rahman, I. A., Lautenschlager, S., Cunningham, J. A., Asher, R. J., Barrett, P. M., Bates, K. T., Bengston, S., Benson, R. B. J., Boyer, D. M., Braga, J., Bright, J. A., Claessens, L. P. A. M., Cox, P. G., Dong, X. P., Evans, A. R., Falkingham, P. L., Friedman, M., Garwood, R. J., Goswami, A., Hutchinson, J. R., Jefferey, N. S., Johanson, Z., Lebrun, R., Martinez-Perez, C., Maragun-Lobon, J., O'Higgins, P. M., Metscher, B., Orliac, M., Rowe, T. B., Rucklin, M., Sanchez-Villagra, M. R., Shubin, N. H., Smith, S. T., Starck, J. M., Stringer, C., Summers, A. P., Sutton, M. D., Walsh, S. A., Weisbecker, V., Witmer, L. M., Wroe, S., Yun, Z., Rayfield, E. J. \& Donoghue, P. C. K. (2017). Open data and digital morphology. Proc. R. Soc. B 284, No. 1852, article 20170194, https://doi.org/10.1098/rspb.2017. 0194.

Dean, M. N., Bizarro, J. J. \& Summers, A. P. (2007). The evolution of cranial design, diet and feeding mechanisms in batoid fishes. The evolution of feeding mechanisms in vertebrates. Integr. Comp. Biol. 47, No. 1, 70-81, https://doi.org/10.1093/icb/ icm034.

DeJong, J. T., Fritzges, M. B. \& Nusslein, K. (2006). Microbially induced cementation to control sand response to undrained shear. J. Geotech. Geoenviron. Engng 132, No. 11, 1381-1392, https://doi.org/10.1061/(ASCE)1090-0241(2006)132:11(1381).

DeJong, J. T., Soga, K. S., Kavazanjian, E., Burns, S., van Paassen, L., Al Qabany, A., Aydilek, A., Bang, S. S., Burbank, M., Caslake, L., Chen, C. Y., Cheng, X., Chu, J., Ciurli, S., Fauriel, S., Filet, A. E., Hamdan, N., Hata, T., Inagaki, Y., Jefferis, S., Kuo, M., Laloui, L., Larrahondo, J., Manning, D. A. C., Martinez, B., Montoya, B. M., Nelson, D. C., Palomino, A., Renforth, P., Santamarina, J. C., Seagren, E. A., Tanyu, B., Tsesarsky, M. \& Weaver, T. (2013). Biogeochemical processes and geotechnical applications: progress, opportunities, and challenges. Géotechnique 63, No. 4, 287-301, https://doi.org/10.1680/geot.SIP13.P.017.

DeJong, J. T., Burrall, M., Wilson, D. W. \& Frost, J. D. (2017). A bio-inspired perspective for geotechnical engineering innovation. In Geotechnical frontiers 2017: geotechnical materials, modeling, and testing (eds T. L. Brandon and R. J. Valentine), Geotechnical Special Publication 280, pp. 862-870. Reston, VA, USA: American Society of Civil Engineers. 
Del Dottore, E., Mondini, A., Sadeghi, A., Mattoli, V. \& Mazzolai, B. (2018). An efficient soil penetration strategy for explorative robots inspired by plant root circumnutation movements. Bioinsp. Biomim. 13, No. 1, https://doi.org/10. 1088/1748-3190/aa9998.

Dorgan, K. M. (2015). The biomechanics of burrowing and boring. J. Expl Biol. 215, No. 2, 176-183, https://doi.org/10.1242/jeb. 086983.

Dorgan, K. M. (2018). Kinematics of burrowing by peristalsis in granular sands. J. Expl Biol. 221, No. 10, jeb167759.

Dorgan, K. M., Jumars, P. A., Johnson, B., Bourdeau, B. P. \& Landis, E. (2005). Burrow extension by crack propagation. Nature 433, No. 475, https://doi.org/10.1038/433475a.

Dorgan, K. M., Arwade, S. R. \& Jumars, P. A. (2007). Burrowing in marine muds by crack propagation: kinematics and forces. J. Expl Biol. 210, No. 23, 4198-4212.

Dudley, R. \& Gans, C. (1991). A critique of symmorphosis and optimality models in physiology. Physio. Biochem. Zoo. 64, No. 3, 627-637, https://doi.org/10.1086/physzool.64.3.30158197.

Endler, J. (1986). Natural selection in the wild. Monographs in population biology. Princeton, NJ, USA: Princeton University Press.

Ennos, A. R. (1993). The scaling of root anchorage. J. Theor. Biol. 161, No. 1, 61-75, https://doi.org/10.1006/jtbi.1993.1040.

Espinoza, N. D. \& Santamarina, J. C. (2010). Ant tunneling - a granular media perspective. Granul. Matter 12, No. 6, 607-616, https://doi.org/10.1007/s10035-010-0202-y.

Farran, L., Ennos, A. R., Starkie, M. \& Eichhorn, S. J. (2009). Tensile and shear properties of fingernails as a function of a changing humidity environment. J. Biomech. 42, No. 9, 1230-1235, https://doi.org/10.1016/j.jbiomech.2009.03.020.

Fayemi, P. E., Wanieck, K., Zollfrank, C., Maranzana, N. \& Aoussat, A. (2017). Biomimetics: process, tools and practice. Bioinsp. Biomim. 7, No. 1, 011002, https://doi.org/10. 1088/1748-3190/12/1/011002.

Fish, F. E. \& Beneski, J. T. (2014). Evolution and bio-inspired design: natural limitations. In Biologically inspired design (eds A. K. Goel, D. A. McAdams and R. B. Stone), pp. 287-312. London, UK: Springer.

Fourcaud, T., Blaise, F., Lac, P., Castéra, P. \& De Reffye, P. (2003). Numerical modelling of shape regulation and growth stresses in trees. Trees 17, No. 1, 31-39, https://doi.org/10.1007/s00468002-0202-6.

Franks, N. R., Worley, A., Falkenberg, M., Sendova-Franks, A. B. \& Christensen, K. (2019). Digging the optimum pit: antlions, spirals and spontaneous stratification. Proc. $R$. Soc. B 286, No. 1899, 20190365, https://doi.org/10.1098/rspb.2019. 0365.

Fratzl, P. (2007). Biomimetic materials research: what can we really learn from nature's structural materials? $J$. $R$. Soc. Interface 4, No. 15, 637-642, https://doi.org/10.1098/rsif.2007. 0218

Frost, J. D., Martinez, A., Mallett, S. D., Roozbahani, M. M. \& DeJong, J. T. (2017). The intersection of modern soil mechanics with ants and roots. In Geotechnical frontiers 2017: geotechnical materials, modeling, and testing (eds T. L. Brandon and R. J. Valentine), Geotechnical Special Publication 280, pp. 900-909. Reston, VA, USA: American Society of Civil Engineers.

Fu, K., Moreno, D., Yang, M. \& Wood, K. L. (2014). Bio-inspired design: an overview investigating open questions from the broader field of design-by-analogy. J. Mech. Des. 136, No. 11, https://doi.org/10.1115/1.4028289.

Full, R. J. \& Koditschek, D. E. (1999). Templates and anchors: neuromechanical hypotheses of legged locomotion on land. J. Expl Biol. 202, No. 23, 3325-3332.

Gignac, P. M. \& Kley, N. J. (2014). Iodine-enhanced micro CT imaging: methodological refinements for the study of the soft-tissue anatomy of post embryonic vertebrates. $J$. Expl Zool. B: Mol. Dev. Evol. 322, No. 2, 166-176, https://doi. org/10.1002/jez.b.22561

Goel, A. K., Vattam, S., Wiltgen, B. \& Helms, M. (2014). Information-processing theories of biologically inspired design. In Biologically inspired design - computational methods and tools (eds A. K. Goel, D. A. McAdams and R. B. Stone), pp. 127-152. London, UK: Springer.
Gosline, J. M., DeMont, M. E. \& Denny, M. W. (1986). The structure and properties of spider silk. Endeavour 10, No. 1, 37-43, https://doi.org/10.1016/0160-9327(86)90049-9.

Gosline, J. M., Guerette, P. A., Ortlepp, C. S. \& Savage, K. N. (1999). The mechanical design of spider silks: from firboin sequence to mechanical function. J. Exp. Biol. 202, No. 23, 3295-3303, https://doi.org/10.1242/jeb.202.23.3295.

Gravish, N. \& Lauder, G. V. (2018). Robotics-inspired biology. J. Expl Biol. 221, No. 7, jeb138438, https://doi.org/10.1242/jeb. 138438.

Gray, J. \& Lissmann, H. W. (1950). The kinetics of locomotion of the grass-snake. J. Expl Biol. 26, No. 4, 354-367.

Gray, D. H. \& Ohashi, H. (1983). Mechanics of fiber reinforcement in sand. J. Geotech. Geoenviron. Engng 109, No. 3, 335-353, https://doi.org/10.1061/(ASCE)0733-9410(1983)109:3(335).

Gray, D. H. \& Sotir, R. B. (1996). Biotechnical and soil bioengineering slope stabilization: a practical guide for erosion control. New York, NY, USA: Wiley.

Greacen, E. L. \& Oh, J. S. (1972). Physics of root growth. Nat. New Biol. 53, 24-25, https://doi.org/10.1038/newbio235024a0.

Gregory, P. J. (2006). Roots, rhizosphere and soil: the route to a better understanding of soil science? Eur. J. Soil. Sci. 57, No. 1, 2-12, https://doi.org/10.1111/j.1365-2389.2005.00778.x.

Grime, J. P. (1977). Evidence for the existence of three primary strategies in plants and its relevance to ecological and evolutionary theory. Am. Nat. 111, No. 982, 1169-1194.

Gunther, B. (1975). Dimensional analysis and theory of biological similarity. Physiol. Rev. 55, No. 4, 659-699.

Hamza, O., Bengough, A. G., Bransby, M. F., Davies, M. C. R. \& Hallett, P. D. (2007). Mechanics of root-pullout from soil: a novel image and stress analysis procedure. In Eco- and ground bio-engineering: The use of vegetation to improve slope stability (eds A. Stokes, I. Spanos, J. E. Norris and E. Cammeraat), pp. 213-221. Dordrecht, the Netherlands: Springer.

Hazel, J., Stone, M., Grace, M. S. \& Tsukruk, V. V. (1999). Nanoscale design of snake skin for reptation locomotion via friction anisotropy. J. Biomech. 32, No. 5, 477-484, https://doi. org/10.1016/S0021-9290(99)00013-5.

Helms, M., Vattam, S. \& Goel, A. K. (2009). Biologically inspired design: process and products. Des. Stud. 30, No. 5, 606-622.

Hemmati, S., Gatmiri, B., Cui, Y. J. \& Vincent, M. (2012). Thermo-hydro-mechanical modelling of soil settlements induced by soil-vegetation-atmosphere interactions. Engng Geol. 139-140, 1-16, https://doi.org/10.1016/j.enggeo.2012. 04.003 .

Hu, D. L., Nirody, J., Scott, T. \& Shelley, M. J. (2009). The mechanics of slithering locomotion. Proc. Natl Acad. Sci. 106, No. 25, 10081-10085, https://doi.org/10.1073/pnas. 0812533106.

Huang, L. \& Martinez, A. (2020). Study of interface frictional anisotropy at bioinspired soil-structure interfaces with compliant asperities. In Geo-congress 2020: biogeotechnics (eds E. Kavazajian, J. P. Hambleton, R. Makhnenko and A. S. Budge), Geotechnical Special Publication 320, pp. 253-261. Reston, VA, USA: American Society of Civil Engineers.

Huang, L. \& Martinez, A. (2021). Load transfer anisotropy at snakeskin-inspired clay-structure interfaces. In IFCEE 2021: from traditional to emerging geotechnics (eds C. El Mohtar, S. Kulesza, T. Baser and M. D. Venezia), Geotechnical Special Publication 320, pp. 119-129. Reston, VA, USA: American Society of Civil Engineers.

Huang, S. \& Tao, J. (2018). Modeling of the burrowing mechanism by razor clam: role of penetration kinematics. In IFCEE 2018: advances in geomaterial modeling and site characterization (eds A. W. Stuedlein, A. Lemnitzer and M. T. Suleiman), Geotechnical Special Publication 295, pp. 547-556. Reston, VA, USA: American Society of Civil Engineers.

Huang, S. \& Tao, J. (2020). Modeling clam-inspired burrowing in dry sand using cavity expansion theory and DEM. Acta Geotech. 15, 2305-2326, https://doi.org/10.1007/s11440-02000918-8.

Huang, S., Tang, Y., Bagheri, H., Li, D., Ardente, A., Aukes, D., Marvi, H. \& Tao, J. (2020). Effects of friction anisotropy on upward burrowing behavior of soft robots in granular materials. Adv. Intell. Syst. 2, No. 6, 1900183, https://doi.org/10.1002/aisy. 201900183. 
Huising, E. J. \& Gomes Pereira, L. M. (1998). Errors and accuracy estimates of laser data acquired by various laser scanning systems for topographic applications. ISPRS J. Photogramm. Remote Sens. 53, No. 5, 245-261, https://doi.org/10.1016/ S0924-2716(98)00013-6.

Irschick, D. J. \& Higham, T. (2016). Animal athletes: an ecological and evolutionary approach. Oxford, UK: Oxford University Press.

Jackson, A. P., Vincent, J. F. V. \& Turner, R. M. (1988). The mechanical design of nacre. Proc. R. Soc. Lond. B 234, No. 1277, 415-440, https://doi.org/10.1098/rspb.1988.0056.

Joffe, I., Hepburn, H. R., Nelson, K. J. \& Green, N. (1975). Mechanical properties of a crustacean exoskeleton. Comp. Biochem. Physiol. 50, No. 3, 545-549, https://doi.org/10. 1016/0300-9629(75)90312-6.

Jouquet, P., Tessier, D. \& Lepage, M. (2004). The soil structural stability of termite nests: role of clays in Macrotermes bellicosus (Isoptera, Macrotermitinae) mound soils. Eur. J. Soil Biol. 40, No. 1, 23-29, https://doi.org/10.1016/j.ejsobi.2004.01.006.

Kandasami, R. K., Borges, R. M. \& Murthy, T. G. (2016). Effect of biocementation on the strength and stability of termite mounds. Environ. Geotech. 3, No. 2, 99-113.

Kar, A. K. (2016). Bio inspired computing - a review of algorithms and scope of applications. Expert Syst. Appl. 59, 20-32, https://doi.org/10.1016/j.eswa.2016.04.018.

Katariya, L., Ramesh, P. B. \& Borges, R. M. (2018). Dynamic environments of fungus-farming termite mounds exert growthmodulating effects on fungal crop parasites. Environ. Microbiol. 20, No. 3, 971-979.

Khosravi, A., Martinez, A., DeJong, J. T. \& Wilson, D. (2018). Discrete element simulations of bio-inspired self-burrowing probes in sands of varying density. Proceedings of biomediated and bioinspired geotechnics conference, Atlanta, GA, USA.

King, H., Ocko, S. \& Mahadevan, L. (2015). Termite mounds harness diurnal temperature oscillations for ventilation. Proc. Natl Acad. Sci. USA 112, No. 37, 11589-11593, https://doi. org/10.1073/pnas. 1423242112.

Lauder, G. V. (1982). Historical biology and the problem of design. J. Theor. Biol. 97, No. 1, 57-67.

Lauder, G. (1996). The argument from design. In Adaptation (eds M. R. Rose and G. V. Lauder), pp. 55-91. San Diego, CA, USA: Academic Press.

Leung, A. K., Garg, A. \& Ng, C. W. W. (2015a). Effect of plant roots on soil-water retention and induced suction in vegetated soil. Engng Geol. 193, 183-197, https://doi.org/10.1016/j.enggeo. 2015.04.017.

Leung, A. K., Gard, A., Coo, J. L., Ng, C. W. W. \& Hau, B. C. H. (2015b). Effects of the roots of Cynodon dactylon and Schefflera heptaphylla on water infiltration rate and soil hydraulic conductivity. Hydrol. Processes 29, No. 15, 3342-3354, https://doi.org/10.1002/hyp.10452.

Li, C., Zhang, T. \& Goldman, D. I. (2013). A terradynamics of legged locomotion on granular media. Science 339, No. 6126, 1408-1412, https://doi.org/10.1126/science.1229163.

Macdonald, I., Ferry, L., Summers, A. \& Gibb, A. (2014). Do Pacific sandfish (Trichodon trichodon) use a modified two-phase respiratory pump for rapid burial? In Proceedings of Society for Integrative and Comparative Biology 2014 annual meeting, p. 129. Herndon, VA, USA: Society for Integrative and Comparative Biology.

Mak, T. W. \& Shu, L. H. (2004). Abstraction of biological analogies for design. CIRP Ann. - Mfg Technol. 53, No. 1, $117-120$.

Maladen, R. D., Ding, Y., Umbanhowar, P. B., Kamor, A. \& Goldman, D. I. (2011). Mechanical models of sandfish locomotion reveal principles of high performance sand-swimming. J. R. Soc. Interface 8, No. 62, 1332-1345, https://doi.org/10.1098/rsif.2010.0678.

Mallett, S., Matsumura, S. \& Frost, J. D. (2018). Additive manufacturing and computed tomography of bio-inspired anchorage systems. Géotechnique Lett. 8, No. 3, 219-225, https://doi.org/10.1680/jgele.18.00090.

Martinez, A. \& O'Hara, K. B. (2021). Skin friction directionality in monotonically- and cyclically-loaded bio-inspired piles in sand. Deep Found. Inst. J. (in press).

Martinez, A., O'Hara, K. B., Sinha, S. K., Wilson, D. \& Ziotopoulou, K. (2018). Monotonic and cyclic centrifuge testing of snake skin-inspired piles. Proceedings of biomediated and bioinspired geotechnics conference, Atlanta, GA, USA.

Martinez, A., Palumbo, S. \& Todd, B. D. (2019). Bio-inspiration for anisotropic load transfer at soil-structure interfaces. J. Geotech. Geoenviron. Engng 145, No. 10, https://doi.org/10.1061/(ASCE) GT.1943-5606.0002138.

Martinez, A., DeJong, J. T., Jaeger, R. A. \& Khosravi, A. (2020). Evaluation of self-penetration potential of a bio-inspired site characterization probe by cavity expansion analysis. Can. Geotech. J. 57, No. 5, 706-716, https://doi.org/10.1139/cgj2018-0864.

Marvi, H., Bridges, J. \& Hu, D. L. (2013). Snakes mimic earthworms: propulsion using rectilinear travelling waves. J. R. Soc. Interface 10, No. 84, 20130188, https://doi.org/10.1098/rsif.2013.0188.

Marvi, H., Gong, C., Gravish, N., Astley, H., Travers, M., Hatton, R. L., Mendelson, J. R., Choset, H., Hu, D. L. \& Goldman, D. I. (2014). Sidewinding with minimal slip: snake and robot ascend of sandy slopes. Science 346, No. 6206, 224-229, https://doi.org/10.1126/science.1255718.

Mazouchova, N., Gravish, N., Savu, A. \& Goldman, D. I. (2010). Utilization of granular solidification during terrestrial locomotion of hatchling sea turtles. Biol. Lett. 6, No. 3, 398-401, https://doi.org/10.1098/rsbl.2009.1041.

McInroe, B., Astley, H. C., Gong, C., Kawano, S. M., Schiebel, P. E., Rieser, J. M., Choset, H., Blob, R. W. \& Goldman, D. I. (2016). Tail use improves performance on soft substrates in models of early vertebrate land locomotors. Science 353, No. 6295, 154-158, https://doi.org/10.1126/science. aaf0984.

McInroe, B., Goldman, D. I. \& Full, R. J. (2018). Substrate volume fraction predicts burrowing dynamics in sand crabs. In Proceedings of Society for Integrative and Comparative Biology 2018 annual meeting, p. 271. Herndon, VA, USA: Society for Integrative and Comparative Biology.

McKee, A., MacDonald, I., Farina, S. C. \& Summers, A. P. (2016). Undulation frequency affects burial performance in living and model flatfishes. Zoology 119, No. 2, 75-80, https://doi.org/ 10.1016/j.zool.2015.12.004.

McMahon, T. (1973). Size and shape in biology: elastic criteria impose limits on biological proportions, and consequently on metabolic rates. Science 179, No. 4079, 1201-1204.

Meyers, M. A., Chen, P. Y., Lin, A. Y. M. \& Seki, Y. (2008). Biological materials: structure and mechanical properties. Prog. Mater. Sci. 53, No. 1, 1-206, https://doi.org/10.1016/j.pmatsci. 2007.05.002.

Mickovski, S. B., Stokes, A., van Beek, R., Ghestem, M. \& Fourcaud, T. (2007). Simulation of direct shear tests on rooted and non-rooted soil using finite element analysis. Ecol. Engng 37, No. 10, 1523-1532, https://doi.org/10.1016/j.ecoleng.2011. 06.001 .

Monaenkova, D., Gravish, N., Rodriguez, G., Kutner, R., Goodisman, M. A. D. \& Goldman, D. I. (2015). Behavioral and mechanical determinants of collective subsurface nest excavation. J. Expl Biol. 218, No. 9, 1295-1305, https://doi.org/10.1242/jeb.113795.

Mullen, J. L., Turk, E., Johnson, K., Wolverton, C., Ishikawa, H., Simmons, C., Soll, D. \& Evans, M. L. (1998). Root-growth behavior of the Arabidopsis mutant rgr1. Plant Physiol. 118, No. 4, 1139-1145, https://doi.org/10.1104/pp.118.4.1139.

Murphy, K. D., McCartney, J. S. \& Henry, K. S. (2015). Evaluation of thermo-mechanical and thermal behavior of full-scale energy foundations. Acta Geotech. 10, No. 2, 179-195, https://doi.org/ 10.1007/s11440-013-0298-4.

Naclerio, N. D., Hubiski, C. M., Aydin, T. O., Goldman, D. I. \& Hawkes, E. W. (2018). Soft robotic burrowing device with tip-extension and granular fluidization. In 2018 IEEE/RSJ international conference on intelligent robots and systems (IROS), pp. 5918-5923, https://doi.org/10.1109/IROS.2018. 8593530. Piscataway, NJ, USA: Institute of Electrical and Electronics Engineers.

Ng, C. W. W., Woon, K. X., Leung, A. K. \& Chu, L. M. (2013). Experimental investigation of induced suction distribution in a grass-covered soil. Ecol. Engng 52, 219-223, https://doi.org/10. 1016/j.ecoleng.2012.11.013.

O’Hara, K. B. \& Martinez, A. (2020). Monotonic and cyclic frictional resistance directionality in snakeskin-inspired surfaces and piles. 
J. Geotech. Geoenviron. Engng 146, No. 11, 04020116, https:// doi.org/10.1061/(ASCE)GT.1943-5606.0002368.

Ortiz, D., Gravish, N. \& Tolley, M. T. (2019). Soft robot actuation strategies for locomotion in granular substrates. IEEE Robot. Autom. Lett. 4, No. 3, 2630-2636, https://doi.org/10.1109/LRA. 2019.2911844.

Pal, S. (2014). Design of artificial human joints and organs. New York, NY, USA: Springer Science+Business Media.

Patino-Ramirez, F. \& Arson, C. (2020). Transportation networks inspired by leaf venation algorithms. J. Bioinspir. Biomim. 15, No. 3, 036012, https://doi.org/10.1088/1748-3190/ab7571.

Quillin, K. J. (2000). Ontogenetic scaling of burrowing forces in the earthworm Lumbricus terrestris. J. Expl Biol. 203, No. 18, 2757-2770.

Rayfield, E. J. (2007). Finite element analysis and understanding the biomechanics and evolution of living and fossil organisms. Annu. Rev. Earth Planet. Sci. 35, 541-576, https://doi.org/10. 1146/annurev.earth.35.031306.140104.

Rieser, J. M., Li, T. D., Tingle, J. L., Goldman, D. I. \& Mendelson, J. R. (2021). Functional consequences of convergently evolved microscopic skin features on snake locomotion. Proc. Natn. Acad. Sci. 118, No. 6, e2018264118, https://doi.org/10.1073/ pnas. 2018264118.

Ruiz, S., Or, D. \& Schymanski, S. J. (2015). Soil penetration by earthworms and plant roots - mechanical energetics of bioturbation of compacted soils. PLoS One 10, No. 6, 1-26.

Runions, A., Fuhrer, M., Lane, B., Federl, P., Rolland-Lagan, A. G. \& Prusinkiewicz, P. (2005). Modeling and visualization of leaf venation patterns. ACM Trans. Graphics 24, No. 3, 702-711, https://doi.org/10.1145/1073204.1073251.

Sadeghi, A., Tonazzini, A., Popova, L. \& Mazzolai, B. (2014). A novel growing device inspired by plant root soil penetration behaviors. PLoS One 9, No. 2, e90139, https://doi.org/10. 1371/journal.pone.0090139.

Santamarina, J. C. (2001). Soil behavior at the microscale: particle forces. In Proceedings of symposium on soil behavior and soft ground construction (eds J. T. Germaine, T. C. Sheahan and R. V. Whitman), pp. 25-56. Reston, VA, USA: American Society of Civil Engineers.

Santamarina, J. C., Klein, K. A. \& Fam, M. A. (2001). Soils and waves - particulate materials behavior, characterization and process monitoring. New York, NY, USA: Wiley.

Savioli, A., Viggiani, C. \& Santamarina, J. C. (2014). Root-soil mechanical interaction. In Geo-congress 2014 technical papers: geocharacterization and modeling for sustainability (eds M. Abu-Farsakh, X. Yu and L. R. Hoyos), Geotechnical Special Publication 234, pp. 3977-3984. Reston, VA, USA: American Society of Civil Engineers.

Sharpe, S. S., Kuckuk, R. \& Goldman, D. I. (2015). Controlled preparation of wet granular media reveals limits to lizard burial ability. Phys. Biol. 12, No. 4, https://doi.org/10.1088/14783975/12/4/046009.

Shin, H. \& Santamarina, J. C. (2011). Open-mode discontinuities in soils. Géotechnique Lett. 1, No. 4, 95-99, https://doi.org/10. 1680/geolett.11.00014.

Soga, K. (2011). Embodied energy and gas emission of geotechnical infrastructure. In Geotechnics and earthquake geotechnics towards global sustainability (ed. S. Iai), pp. 59-74, https://doi. org/10.1007/978-94-007-0470-1_4. Dordrecht, the Netherlands: Springer.

Stokes, A., Drexhage, M. \& Guitard, D. (2000). A method for predicting the possible site of failure in trees during mechanical loading. In The supporting roots of trees and woody plants: form, function and physiology (ed. A. Stokes), pp. 279-285. Dordrecht, the Netherlands: Springer.

Stutz, H. H., Martinez, A., Heepe, L., Tramsen, H. T. \& Gorb, S. N. (2019). Strength anisotropy at soil-structure interfaces with snake skin inspired structural surfaces. ES3 Web Conf. 92, article 13008, https://doi.org/10.1051/e3sconf/20199213008.

Summers, A. D. \& O'Reilly, J. C. (1997). A comparative study of locomotion in the caecilians Dermophis mexicanus and Typhlonectes natans (Amphibia: Gymnophiona). Zool. J. Linnean Soc. 121, No. 1, 65-76.

Switala, B. M. \& Wu, W. (2018). Numerical modelling of rainfall-induced instability of vegetated slopes. Géotechnique 68, No. 6, 481-491, https://doi.org/10.1680/jgeot.16.P.176.
Tao, J., Huang, S. \& Tang, Y. (2019). Bioinspired self-burrowing-out robot in dry sand. J. Geotech. Geoenviron. Engng 145, No. 12, 02819002, https://doi.org/10.1061/(ASCE)GT.1943-5606. 0002177.

Tao, J., Huang, S. \& Tang, Y. (2020). SBOR: a minimalistic soft self-burrowing-out robot inspired by razor clams. Bioinspir. Biomim. 15, No. 5, 055003, https://doi.org/10.1088/1748-3190/ ab8754.

Taylor, I., Lehner, K., McCaskey, R., Nirmaal, N., Ozkan-Aydin, Y., Murray-Cooper, M., Jain, R., Hawkes, E. W., Ronald, P. C., Goldman, D. I. \& Benfey, P. N. (2021). Mechanism and function of root circumnutation. Proc. Natn. Acad. Sci. 118, No. 8, e2018940118, https://doi.org/10.1073/pnas.2018940118.

Tombolato, L., Novitskaya, E. E., Chen, P. Y., Sheppard, F. A. \& McKittrick, J. (2010). Microstructure, elastic properties and deformation mechanisms of horn keratin. Acta Biomater: 6, No. 2, 319-330, https://doi.org/10.1016/j.actbio.2009.06.033.

Trueman, E. R. (1968). The burrowing activities of bivalves. Symp. Zool. Soc. Lond. 22, 167-186.

Trueman, E. R. (1970). The mechanism of burrowing of the mole crab, Emerita. J. Expl Biol. 53, No. 3, 701-710, https://doi.org/ 10.1242/jeb.53.3.701.

Tuculescu, R., Topoff, H. \& Wolfe, S. (1975). Mechanisms of pit construction by antlion larvae. Ann. Entomol. Soc. Am. 68, No. 4, 719-720, https://doi.org/10.1093/aesa/68.4.719.

Turcotte, M. M. \& Levine, J. M. (2016). Phenotypic plasticity and species coexistence. Trends Ecol. Evol. 31, No. 10, 803-813, https://doi.org/10.1016/j.tree.2016.07.013.

Turner, J. S. (2005). Extended physiology of an insect-built structure. Am. Entomol. 51, No. 1, 36-38.

Turner, J. S. \& Soar, R. M. (2008). Beyond biomimicry. What termites can tell us about realizing the living building. In Proceedings of the 1st international conference on industrialised, integrated, intelligent construction (eds T. A. Hassan and J. Ye), pp. 234-248. Loughborough, UK: Loughborough University.

Ueda, K., Hatono, I., Fujii, N. \& Vaario, J. (2001). Lineless production system using self-organization: a case study for BMS. Ann. CIRP 50, No. 1, 319-322, https://doi.org/10.1016/S00078506(07)62130-1.

van der Rijt, J. A. J., van der Werf, K. O., Bennink, M. L., Dijkstra, P. J. \& Feijen, J. (2006). Micromechanical testing of individual collagen fibrils. Macromol. Biosci. 6, No. 9, $697-702$.

van Noordwijk, M. \& De Willigen, P. (1987). Agricultural concepts of roots: from morphogenetic to functional equilibrium between root and shoot growth. Neth. J. Agric. Sci. 35, No. 4, 487-496.

Vesala, R., Harjuntausta, A., Hakkarainen, A., Rönnholm, P., Pellikka, P. \& Rikkinen, J. (2019). Termite mound architecture regulates nest temperature and correlates with species identities of symbiotic fungi. PeerJ 6, e6237.

Vogel, S. (1998). Cat's paws and catapults: mechanical worlds of nature and people. New York, NY, USA: W. W. Norton \& Company, Inc.

Vogel, S. (2013). Comparative biomechanics, life's physical world, 2nd edn. Princeton, NJ, USA: Princeton University Press.

Wainright, S. A., Biggs, W. D., Currey, J. D. \& Gosline, J. M. (1982). Mechanical design in organisms. Princeton, NJ, USA: Princeton University Press.

Wegst, U. G. K. \& Ashby, M. F. (2004). The mechanical efficiency of natural materials. Phil. Mag. 84, No. 21, 2167-2186, https://doi.org/10.1080/14786430410001680935.

Wenger, M. P. E., Bozec, L., Horton, M. A. \& Mesquida, P. (2007). Mechanical properties of collagen fibrils. Biophys. J. 93, No. 4, 1255-1263, https://doi.org/10.1529/biophysj.106.103192.

Whiffin, V. S., van Paassen, L. A. \& Harkes, M. P. (2007). Microbial carbonate precipitation as a soil improvement technique. Geomicrobiol. J. 24, No. 5, 417-423, https://doi.org/10. 1080/01490450701436505.

Winter, A. G., Deits, R. L. H. \& Hosoi, A. E. (2012). Localized fluidization burrowing mechanics of Ensis directus. J. Expl Biol. 215, No. 12, 2072-2080.

Wroe, S., Huber, D. R., Lowry, M., McHenry, C., Moreno, K., Clausen, P., Ferrara, T. L., Cunningham, E., Dean, M. N. \& Summers, A. P. (2008). Three-dimensional computer analysis of white shark jaw mechanics: how hard can a great white 
bite? J. Zool. 276, No. 4, 336-342, https://doi.org/10.1111/ j.1469-7998.2008.00494.x.

Yamamoto, K. Y., Vangla, P. \& Frost, J. D. (2019). 2D and 3D laboratory studies to understand tunneling behavior of Pogonomyrmex occidentalis in different soil conditions. In Proceedings of Society for Integrative and Comparative Biology 2019 annual meeting, p. 256. Herndon, VA, USA: Society for Integrative and Comparative Biology.
Yen, J., Weissburg, M. J., Helms, M. \& Goel, A. K. (2011). Biologically inspired design: a tool for interdisciplinary education. In Biomimetics: nature-based innovation (ed. Y. Bar-Cohen), pp. 331-360. Boca Raton, FL, USA: CRC Press.

Zachariah, N., Das, A., Murthy, T. G. \& Borges, R. M. (2017). Building mud castles: a perspective from brick-laying termites. Sci. Rep. 7, No. 1, article 4692. 